\title{
Distributions of $Y+R E E$ and Sc in tourmaline and their implications for the melt evolution; examples from NYF pegmatites of the Třebíč Pluton, Moldanubian Zone, Czech Republic
}

\author{
Renata ČOPJAKOVÁ1*, Radek ŠKODA ${ }^{1}$, Michaela VAŠINOVÁ GALIOVÁ ${ }^{2,3}$, Milan NOVÁK ${ }^{1}$ \\ ${ }^{1}$ Department of Geological Sciences, Masaryk University, Kotlářská 2, 61137 Brno, Czech Republic; copjakova@sci.muni.cz \\ ${ }^{2}$ Department of Chemistry, Faculty of Science, Masaryk University, Kotlářská 2, 61137 Brno, Czech Republic \\ ${ }^{3}$ Central European Institute of Technology (CEITEC), Masaryk University, Kamenice 5, 62500 Brno, Czech Republic \\ * Corresponding author
}

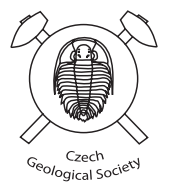

\begin{abstract}
Tourmalines from NYF and mixed (NYF + LCT) pegmatites of the Třebíc Pluton (Moldanubian Zone, Czech Republic) are generally characterized by variable and relatively high concentrations of Y + REE (4-457 ppm) and Sc (18-765 $\mathrm{ppm})$. They show enrichment in LREE ( $\mathrm{Ce}>\mathrm{La}$ ); the chondrite-normalized REE patterns decrease uniformly from La to $\mathrm{Tb}$; $\mathrm{Tb}$ to $\mathrm{Tm}$ are mostly below the detection limits $(<0.01-0.08 \mathrm{ppm})$ and are followed by an upturn to $\mathrm{Yb}$ and $\mathrm{Lu}$. Our textural and paragenetic observations indicate that growth of magmatic tourmaline reflects $Y+R E E$ contents in the melt. Tourmaline is highly compatible with Sc and shows exceptionally high contents of Sc compared to the analyzed host pegmatite units (less than $1 \mathrm{ppm} \mathrm{Sc}$ ). The contents of Sc positively correlate with $\sum \mathrm{Y}+\mathrm{REE}$. Two distinct evolutionary trends of trace-elements in tourmaline were distinguished. (i) A conspicuous increase in Y + REE and Sc in tourmaline (dravite, Ca-rich dravite) from primitive euxenite-type pegmatites reflects their enrichment in the melt with the progressive crystallization and fractionation. It also was enhanced by low $\mathrm{P}\left(<0.02 \mathrm{wt} . \% \mathrm{P}_{2} \mathrm{O}_{5}\right)$ and Ca contents $(<0.8$ wt. \% $\mathrm{CaO})$ in host pegmatite unit preventing precipitation of $\mathrm{Y}+\mathrm{REE}$ phosphates and allanite, respectively. (ii) Tourmaline (schorl, fluor-schorl, fluor-elbaite) from more evolved pegmatites (evolved euxenite-type and mixed (NYF + LCT) pegmatite) show a depletion in REE and Sc with progressive crystallization reflecting most likely the coeval precipitation of REE-rich minerals, especially monazite-(Ce), xenotime-(Y), samarskite- and aeschynite-group minerals. The Eu anomalies in tourmaline vary significantly from positive (up to $\mathrm{Eu} / \mathrm{Eu}^{*} \sim 16$ ) to substantially negative ones and are related to the Eu contents in the melt and degree of its fractionation.
\end{abstract}

Keywords: $Y+R E E$ and Sc, tourmaline composition, melt evolution, LA-ICP-MS, NYF pegmatites, Třebič Pluton Received: 1 March 2013; accepted: 8 June 2013; handling editor: P. Uher

\section{Introduction}

Tourmalines are widely used as compositional (geochemical) indicators of geological processes chiefly due to their ability to incorporate a high number of elements, large stability field in PTX-conditions, and refractory behavior (e.g., Henry and Dutrow 1996; Dutrow and Henry 2011; van Hinsberg et al. 2011a,b). Compositional trends of tourmaline based on EMP data were studied in a variety of granitic rocks (e.g., London and Manning 1995; Buriánek and Novák 2007) and chiefly in granitic pegmatites of the LCT family, from barren (primitive) ones (e.g., Roda et al. 1995; Novák et al. 2004) to more fractionated complex (Li) pegmatites of various subtypes (e.g., Jolliff et al. 1986; Novák and Povondra 1995; Federico et al. 1998; Novák et al. 1999a,b; Selway et al. 1999, 2000; Tindle et al. 2002, 2005; Zhang et al. 2008). However, tourmalines are relatively rare in NYF pegmatites (Ercit et al. 2003; Novák et al. 2011).

Trace elements, including REE, are particularly useful for petrogenetic studies. Published Y + REE data for tourmaline from granitic rocks (e.g., Yavuz et al. 1999; King et al. 1988; Raith et al. 2004; Pesquera et al. 2005; Yavuz et al. 2011) or granitic pegmatites (e.g., Jolliff et al. 1987; Hellingwerf et al. 1994; Roda et al. 1995; Ertl et al. 2006; Novák et al. 2011; Bačík et al. 2012) are uncommon. Compositional trends in tourmalines from granitic pegmatites based on the concentrations of Y + REE and REE patterns in relation to pegmatite family (LCT or NYF), degree of fractionation, and tourmaline origin (magmatic or hydrothermal) are poorly understood (e.g., Jolliff et al. 1987; Bačík et al. 2012). Moreover, comparison of total contents of $\mathrm{Y}+$ REE, REE patterns and their compositional trends from the published data is complicated because of acquisition of data with different analytical methods and/or incomplete determination of the suite of the REE. Lastly, detailed information on coexisting Y,REE-rich minerals is typically absent.

Tourmalines with relatively high contents of Sc (34-293 ppm), La $(\leq 37 \mathrm{ppm})$ and $\mathrm{Ce}(\leq 62.7 \mathrm{ppm})$ were previously described from the NYF pegmatites of the Třebíč Pluton (Novák et al. 2011), but behavior of trace 
elements during the tourmaline growth was not studied in detail. We report and discuss concentrations and behavior of Y + REE in tourmalines from selected pegmatites of the Třebíc Pluton. We focus on the chemistry of tourmaline as it relates to associated Y,REE-rich accessory minerals, to the crystallization sequence and to the degree of fractionation of the melt.

\section{Geological setting}

The Moldanubian Zone is characterized by numerous granitic pegmatites of different origin and mineralogy. The most abundant belong to rare-element class and exhibit substantial variability in size, textural differentiation, degree of fractionation and mineralogy from barren to highly fractionated ones with both LCT $>>$ NYF characteristics according to the current classification schemes (Černý and Ercit 2005; Černý et al. 2012). The pegmatites of the rare-element class (both LCT and NYF) crystallized over a short time period of 340-332 Ma (Novák et al. 1998a; Melleton et al. 2012). Along with numerous LCT pegmatites with abundant tourmalines (Povondra 1981; Povondra et al. 1985; Novák and Povondra 1995; Selway et al. 1998, 1999; Novák et al. 1999a,b, 2004, 2012, 2013), rare accessory tourmaline occurs in the NYF pegmatites derived from the Třebíc Pluton (Novák et al. 2011, 2012).

\subsection{Geology of the Třebíc Pluton}

The large tabular body $\left(\sim 540 \mathrm{~km}^{2}\right)$ of the Třebíč Pluton, corresponding to porphyritic, amphibole-biotite melasyenite to quartz melasyenite and melagranite, was emplaced in medium- to high-grade metamorphic rocks of the Moldanubian Zone. The rocks are metaluminous $($ ASI $=0.85-0.93)$ with high concentrations of $\mathrm{K}_{2} \mathrm{O}$ (5.2-6.9 wt. \%), $\mathrm{MgO}$ (3.0-10.4 wt. \%), $\mathrm{P}_{2} \mathrm{O}_{5}(0.45-0.98$ wt. \%), Rb (330-410 ppm), Ba (1100-2470 ppm), U (6.7-26.2 ppm), Th (28.2-47.8 ppm), Cr (233-659 ppm), Cs (20-40 ppm), Sc (9-27 ppm), high K/Rb (133-171) and high $\mathrm{Rb} / \mathrm{Sr}(0.8-1.3)$, but also unusually low $\mathrm{CaO}$ (2.3-3.8 wt. \%) and $\mathrm{Sr}(281-496 \mathrm{ppm})$ contents (Holub 1997; Janoušek et al. 2000; unpublished data of authors). They exhibit high $\sum Y+$ REE contents (191-447 ppm) with enrichment in LREE $\left(\mathrm{La}_{\mathrm{N}} / \mathrm{Yb}_{\mathrm{N}}=12-30\right)$ and weak negative $\mathrm{Eu}$ anomalies $\left(\mathrm{Eu} / \mathrm{Eu}^{*} \sim 0.7\right)$. The geochemical signature as well as $\mathrm{Sr}$ isotopic ratios $\left({ }^{87} \mathrm{Sr} /{ }^{86} \mathrm{Sr}_{337}=\right.$ $0.7090-0.7125)$ and $\mathrm{Nd}$ isotopic data $\left(\varepsilon_{N d}^{337}=-6.3\right)$ suggest mixing of durbachitic (enriched mantle-derived) magma with leucogranitic anatectic melt (Holub 1997; Janoušek et al. 2000, 2003; Žák et al. 2005). The durbachite suite intruded shortly after exhumation of the high-grade Gföhl Unit to mid-crustal levels at 340-335 Ma (Holub

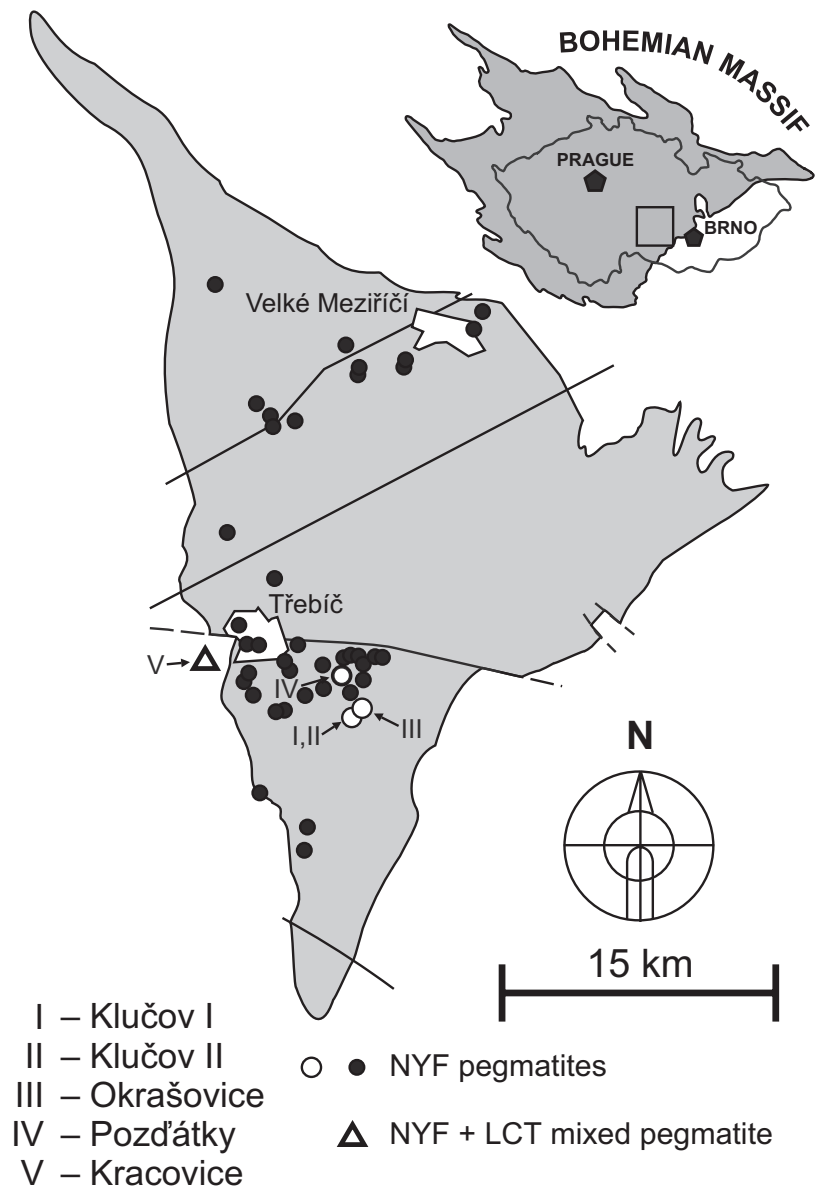

Fig. 1 Schematic map of the Třebíč Pluton. Open symbols - studied localities; full symbols - known NYF pegmatite occurrences.

et al. 1997; Janoušek and Holub 2007; Kotková et al. 2010; Kusiak et al. 2010).

\subsection{NYF pegmatites of the Třebíč Pluton}

Granitic pegmatites of the Třebíč Pluton represent a unique example of the NYF-to-mixed (NYF > LCT) petrogenetic family related to orogenic $I$-type granite (Novák et al. 2012). Several distinct varieties of mostly intragranitic NYF pegmatites were distinguished (Fig. 1; Škoda et al. 2006; Novák et al. 2011, 2012): (a) Subhomogeneous allanite-type pegmatites form small irregular nests and segregations, commonly with transitional contact to the host syenogranite. (b) Lenses, dykes and irregular bodies of simply zoned euxenite-type pegmatites, from $20 \mathrm{~cm}$ to $2 \mathrm{~m}$ thick, and several meters long, are the most common. Starting at the contact, they are zoned with: (i) a fine- to medium-grained granitic unit (Kfeldspar + plagioclase + quartz + biotite), (ii) a graphic unit (K-feldspar + quartz or albite + quartz), (iii) a blocky $\mathrm{K}$-feldspar and (iv) a quartz core; moreover, (v) an albite 
unit is only locally developed in central parts of the pegmatites (Škoda et al. 2006). Tourmaline occurs in the graphic and/or blocky unit. Along with quartz, K-feldspar (locally pale amazonite) and albite (usually $\leq \mathrm{An}_{5}$ ), typical minor-to-subordinate minerals include biotite $\left(\mathrm{X}_{\mathrm{Mg}}\right.$ $=0.49-0.70$ ), black tourmalines and a wide spectrum of accessories, i.e. minerals of aeschynite or euxenite group, allanite-(Ce), ilmenite, titanite, niobian rutile, beryl, and zircon (Škoda et al. 2006; Škoda and Novák 2007; Novák and Filip 2010). (c) The euxenite-type pegmatite Klučov I is very similar to the previous group in geological position, internal structure and mineralogy. However, it is characterized by a common occurrence of amazonite, abundant tourmaline with more evolved chemical composition (Al-, F- and Mn-rich), presence of Sn-bearing minerals (cassiterite, herzenbergite, stokesite), tinzenite and aeschynite-group minerals (Škoda et al. 2006; Škoda and Novák 2007; Novák et al. 2011). Typical feature of the (a) allanite- and (b) euxenite-type pegmatites is their metaluminous composition deduced from the absence of muscovite and garnet and also indicated by tourmaline with $\mathrm{Al}_{\text {total }}$ less than 6 apfu (Novák et al. 2011), and rare beryl; however, the latter two minerals shift the bulk composition to slightly peraluminous field. (d) The most evolved, symmetrically zoned pegmatite dyke in Kracovice, $\sim 1 \mathrm{~m}$ thick and $30 \mathrm{~m}$ long, cuts graphitic gneiss $300 \mathrm{~m} \mathrm{~W}$ of the edge of the Třebíc Pluton (Fig. 1; Němec 1990; Novák et al. 1999b; Škoda et al. 2006). Starting at the contact, the pegmatite consists of: a coarsegrained granitic unit (K-feldspar + plagioclase + quartz + biotite + muscovite + titanite), an abundant graphic unit (K-feldspar + quartz \pm biotite), evolving to minor blocky K-feldspar, and albite complex situated close to a small quartz core in its most differentiated part. Typical minor-to-accessory minerals include tourmaline (schorl to fluor-elbaite), Y,Sc-enriched spessartine, topaz, Li-micas (Mn-rich polylithionite, masutomilite), beryl, cassiterite, zircon, allanite-(Ce), niobian rutile, minerals columbite, fergusonite, samarskite group, wolframoixiolite, F-rich hambergite (Novák et al. 1998b), monazite-(Ce) and xenotime-(Y). Despite the Li-enrichment, this pegmatite shows a strong NYF signature, and could by assigned to the mixed (NYF + LCT) group (Novák et al. 2012). Major, minor and accessory minerals typical of the individual pegmatite types are given in Tab. 1 .

\section{Methods}

\subsection{Sampling and whole-rock chemical analyses}

Samples from the following pegmatite dykes were studied in detail (compare Tab. 1 in Novák et al. 2011): (b) euxenite type - Pozd'átky, Okrašovice, Klučov II, (c) more evolved euxenite-type - Klučov I, and (d) NYF + LCT mixed Kracovice pegmatite. Tourmalines from (a) allanite-type pegmatites (Novák et al. 2011) were not examined. Polished thin sections $(\sim 200 \mu \mathrm{m}$ thick $)$ and polished epoxy mounts from the rock samples with tourmaline were prepared for electron microprobe (EMP) and Laser-Ablation Inductively Coupled Plasma Mass Spectrometry (LA-ICP-MS) investigations. We realized that there are difficulties in obtaining representative bulk chemical compositions of such heterogeneous rocks (zoned pegmatites); hence, the whole-rock analyses were performed only from samples of tourmaline-bearing units in rather primitive euxenite-type pegmatites -

Tab. 1 Overview of the studied tourmaline-bearing pegmatites and their primary mineral assemblages

\begin{tabular}{|c|c|c|c|c|c|}
\hline pegmatite type & locality & tourmaline & composition & $\begin{array}{c}\text { textural-paragenetical unit } \\
\text { of tourmaline; accessory } \\
\text { minerals closely associated } \\
\text { with tourmaline }\end{array}$ & $\begin{array}{c}\text { Y+REE minerals crystallized } \\
\text { after magmatic tourmaline or } \\
\text { from more evolved textural- } \\
\text { paragenetical units }\end{array}$ \\
\hline \multirow{3}{*}{ (b) euxenite type, NYF } & Pozd'átky & $\begin{array}{l}\text { b-Tu1 } \\
\text { b-Tu2 }\end{array}$ & $\begin{array}{c}\text { dravite } \\
\text { Ca-rich dravite }\end{array}$ & blocky unit Kfs > Qz; zircon & none found \\
\hline & Okrašovice & $\begin{array}{l}\text { b-Tu1 } \\
\text { b-Tu2 }\end{array}$ & $\begin{array}{c}\text { dravite } \\
\text { Ca-rich dravite }\end{array}$ & $\begin{array}{c}\text { blocky unit Kfs }>\text { Qz; beryl, } \\
\text { zircon }\end{array}$ & $<1 \mathrm{~mm}$ polycrase-( $(\mathrm{Y})$ \\
\hline & Klučov II & $\begin{array}{l}\text { b-Tu1 } \\
\text { b-Tu2 }\end{array}$ & $\begin{array}{c}\text { dravite } \\
\text { Ca-rich dravite }\end{array}$ & $\begin{array}{l}\text { graphic unit } \mathrm{Kfs}, \mathrm{Qz}>\mathrm{Ab} \text {; } \\
\text { zircon, Nb-rutile }\end{array}$ & $<2$ cm aeschynite- $(\mathrm{Y})$ \\
\hline (c) evolved euxenite type, NYF & Klučov I & $\begin{array}{l}\text { c-Tu1 } \\
\text { c-Tu2 }\end{array}$ & $\begin{array}{c}\text { schorl } \\
\text { Al-, F-rich schorl }\end{array}$ & $\begin{array}{c}\text { graphic unit Kfs, Qz }>\mathrm{Ab} \text {; } \\
\text { cassiterite, columbite-(Mn), } \\
\text { zircon, Nb-rutile, aeschynite- } \\
(\mathrm{Ce}), \text { monazite-(Ce) }\end{array}$ & $<2 \mathrm{~cm}$ nioboaeschynite-(Ce) \\
\hline (d) NYF+LCT mixed type & Kracovice & $\begin{array}{l}\text { d-Tu1 } \\
\text { d-Tu2 }\end{array}$ & $\begin{array}{l}\text { Al-, F-rich schorl } \\
\text { fluor-elbaite }\end{array}$ & $\begin{array}{l}\text { blocky unit Kfs, Qz }>\mathrm{Ab} \text {; } \\
\text { cassiterite, columbite-(Mn), } \\
\text { zircon, Nb-rutile, Y,Sc-rich } \\
\text { spessartine, samarskite-(Y), } \\
\text { monazite-(Ce), xenotime-(Y) }\end{array}$ & $\begin{array}{l}\text { Y,Sc-rich spessartine, samarskite- } \\
(\mathrm{Y}) \text {, fergusonite-(Y), monazite- } \\
\text { (Ce), xenotime-(Y) }\end{array}$ \\
\hline
\end{tabular}


Pozd'átky, Okrašovice and Klučov II. Samples of pegmatites $(\sim 5 \mathrm{~kg})$ were crushed, pulverized and wholerock analyses were performed at the Acme Chemical Laboratories Ltd, Vancouver, Canada. Major elements were determined using ICP-OES after fusion with lithium borate flux. All $\mathrm{Fe}$ is reported as $\mathrm{Fe}_{2} \mathrm{O}_{3}$. Trace elements, including the $\mathrm{Y}+\mathrm{REE}$ and $\mathrm{Sc}$, were analyzed by ICP-MS with additional lithium tetraborate fusion (for analytical details see http://acmelab.com - analytical groups $4 \mathrm{~A}-4 \mathrm{~B}, 2 \mathrm{~A})$.

\subsection{Electron microprobe}

Tourmaline was analyzed by the Cameca SX 100 electron microprobe at the Joint Laboratory of Electron Microscopy and Microanalysis, Department of Geological Sciences, Masaryk University, and Czech Geological Survey, Brno in wavelength dispersive mode and the accelerating voltage $15 \mathrm{kV}$, beam currents $10 \mathrm{nA}$ and a spot size $\sim 5 \mu \mathrm{m}$. The following standards and X-ray $K_{\alpha}$ lines were used for tourmaline analyses: sanidine ( $\mathrm{Si}, \mathrm{Al}, \mathrm{K})$, albite $(\mathrm{Na})$, olivine $(\mathrm{Mg})$, andradite $(\mathrm{Ca}, \mathrm{Fe}), \mathrm{Mn}_{2} \mathrm{SiO}_{4}$ $(\mathrm{Mn})$, anatase (Ti), topaz $(\mathrm{F})$, and $\mathrm{ZnO}(\mathrm{Zn})$. The peak counting times were $10 \mathrm{~s}$ for major and $20-40 \mathrm{~s}$ for minor elements. The background counting time was $1 / 2$ of that on the peak, on the high- and low-energy positions. With regard to the analysis of fluorine, special care was taken to determine the optimal background positions and to minimize the overlap of the $\mathrm{F} K_{\alpha}$ peak with the $\mathrm{Fe} L_{\alpha}$ peak position. The raw data obtained from electron microprobe, supplemented by theoretical B and H contents, were reduced, using appropriate X-Phi matrix corrections (Merlet 1994). Crystal-chemical formulae of tourmaline were calculated on the basis of $\mathrm{Si}=6$ according to the general formula $X Y_{3} Z_{6} T_{6} O_{18}\left(B O_{3}\right)_{3} V_{3} W$, where $X=\mathrm{Na}, \mathrm{Ca}$, $\mathrm{K}$, vacancies; $Y=\mathrm{Fe}, \mathrm{Mg}, \mathrm{Mn}, \mathrm{Ti}, \mathrm{Al}, \mathrm{Zn}, \mathrm{V} ; Z=\mathrm{Al}, \mathrm{Fe}$, $\mathrm{Mg} ; T=\mathrm{Si} ; B=\mathrm{B} ; V+W=\mathrm{OH}+\mathrm{F}+\mathrm{O}=4$ (Hawthorne and Henry 1999; Henry et al. 2011), to normalize the same way in Li-poor dravite to Li-rich fluor-elbaite. All $\mathrm{Fe}$ was considered as $\mathrm{Fe}^{2+}$.

\subsection{Laser-Ablation Inductively Coupled Plasma Mass Spectrometry}

The LA-ICP-MS at the Department of Chemistry, Masaryk University, Brno, consists of a laser-ablation system UP 213 (New Wave, USA) and an ICP-MS spectrometer Agilent 7500 CE (Agilent, Japan). A commercial Q-switched Nd:YAG laser-ablation device works at the $5^{\text {th }}$ harmonic frequency which corresponds to the wavelength of $213 \mathrm{~nm}$. The sample surface was ablated at individual spots for $60 \mathrm{~s}$ per spot by a laser beam in $80 \mu \mathrm{m}$ diameter. Ablation was carried out using the laser pulse fluence of $5 \mathrm{~J} \mathrm{~cm}^{-2}$ and $10 \mathrm{~Hz}$ repetition rate. The signals of isotopes of the following trace elements were measured: Li, Sc, V, Cr, Zn, Sr, Y, Zr, Nb, Sn, Cs, Ba, REE, Hf, Ta, W, Pb, and Th. The contents of elements were calculated using NIST SRM 610 and 612 standards, and $\mathrm{Si}$ as internal reference element after baseline correction and integration of the peak area using GRAMS software (http://www.thermofisher.com).

The areas analyzed by LA-ICP-MS were carefully examined by the EMP prior to the ablation. Along with the geochemically relevant elements incorporated within the tourmaline structure, it was important to recognize undesirable inclusions of monazite (Th, REE), zircon ( $\mathrm{Zr}$, $\mathrm{Hf}, \mathrm{Y}$ and HREE), feldspars (Sr, Ba), cassiterite (Sn) and aeschynite- or euxenite-group minerals $(\mathrm{Nb}, \mathrm{Ti}, \mathrm{Ta}, \mathrm{Y}$, REE, Th) on basis of LA-ICP-MS data. Four LA-ICP-MS analyses, from the total of 120 measurements, were excluded from the dataset due to probable presence of zircon inclusions.

\section{Results}

\subsection{Paragenetic and morphological types of tourmaline and their zoning in BSE images}

All examined tourmaline samples are black-to-brownish black in hand specimen. The (b) euxenite-type pegmatites contain single equidimensional-to-elongated grains and coarse- to medium-grained aggregates, commonly $1-3 \mathrm{~cm}$ in diameter, intergrown in the blocky K-feldspar unit at Pozd'átky and Okrašovice pegmatites. In the Klučov II pegmatite, single tourmaline grains (up to $1 \mathrm{~cm}$ ) occur in the graphic unit. These tourmalines are heterogeneous with isolated dark and light domains in BSE images; the dark ones (b-Tu1) are mostly situated in center of grains and appear to be older, while the lighter domains (b-Tu2) overgrow this early tourmaline (b-Tu1; Fig. 2a-b). Interstitial tourmalines fill intergranular spaces and fractures in K-feldspar or albite (Novák et al. 2011) and were not investigated due to their small size and with respect to detection limits of the LA-ICP-MS analysis.

In the (c) evolved euxenite-type Klučov I pegmatite tourmaline forms graphic intergrowths with quartz, 1-6 $\mathrm{cm}$ in size, with the individual tourmaline hieroglyphs from 1-15 $\mathrm{mm}$. They are located in the graphic unit (amazonitic K-feldspar + quartz) along the contact with the blocky K-feldspar unit. Tourmaline domains (c-Tu1), light in the BSE image, volumetrically predominate in the graphic intergrowths and they are rimmed with, and locally replaced by, tourmaline (c-Tu2) darker in BSE (Fig. $2 \mathrm{c}$ ). In the most evolved (d) Kracovice pegmatite, columnar crystals of black tourmaline $(\leq 6 \mathrm{~cm}$ long) occur 

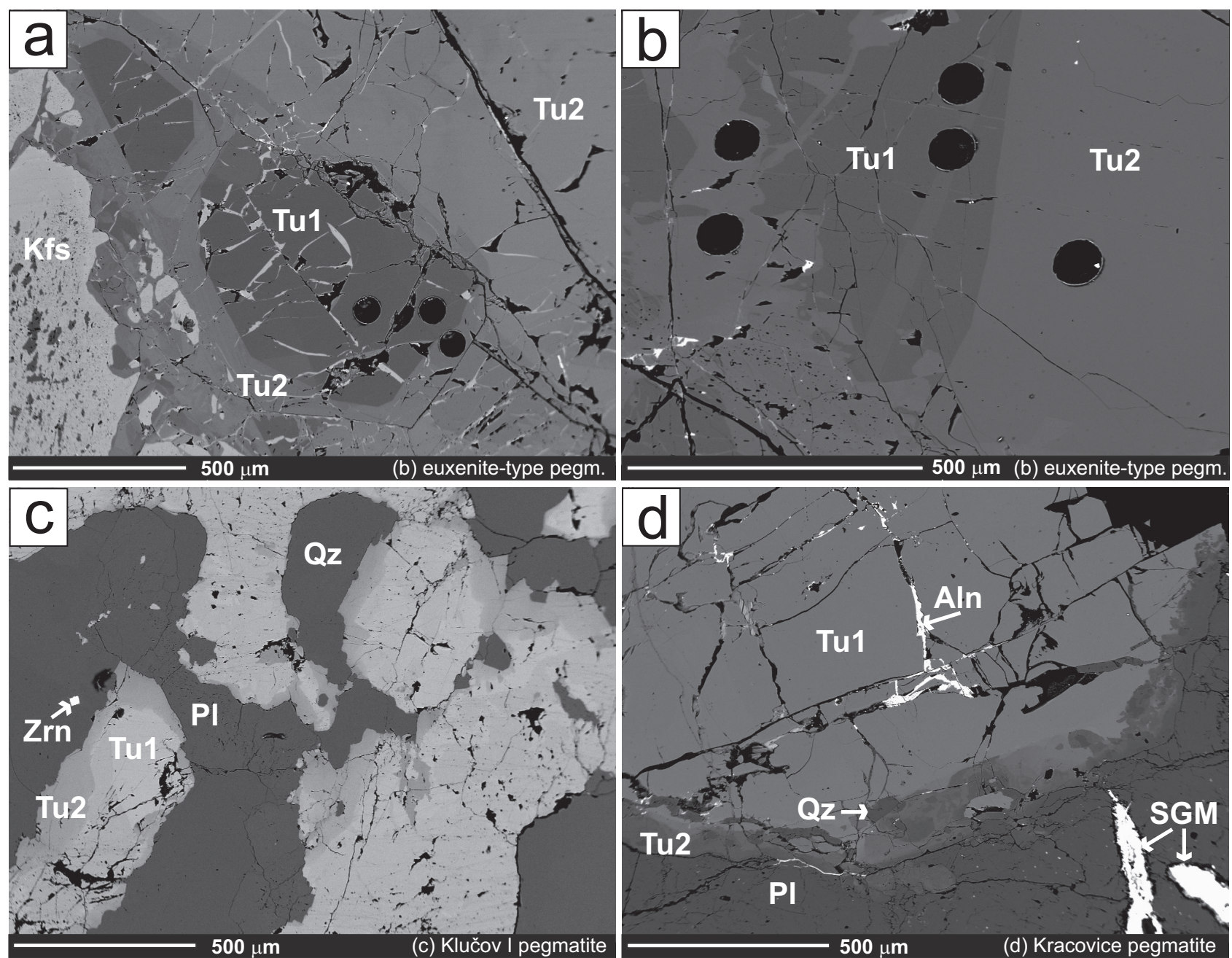

Fig. 2 Back-scattered electron (BSE) images of tourmaline from the euxenite-type pegmatites (a-b), Klučov I pegmatite (c) and Kracovice pegmatite (d). a - Pozd'átky; early dravite (Tu1) overgrown by later generation of Ca-rich dravite (Tu2) and interstitial tourmaline on a contact with perthitic K-feldspar; b - Okrašovice; early dravite (Tu1) partly overgrown and replaced by later Ca-rich dravite (Tu2); c - early schorl (Tu1) rimmed and partly replaced by later fluorine-rich schorl (Tu2) from graphic intergrowths; $\mathbf{d}$ - large, columnar, chemically homogeneous Al-rich schorl (Tu1) crystal partly replaced by later fluor-elbaite (Tu2) along the rim; the bright later mineral (Aln) along the cracks in tourmaline (Tu1) is allanite-(Ce). Black circles are holes left after LA-ICP-MS analyses. The abbreviations for rock-forming minerals are after Whitney and Evans

in the blocky K-feldspar unit. A relatively homogeneous core (d-Tu1), light in BSE, has a thin $(30-500 \mu \mathrm{m})$ dark outer zone (d-Tu2), which shows locally replacement textures (Fig. 2d).

Contacts of both domains (Tu1) and (Tu2) in all examined samples and localities are commonly sharp, with rare transitional or replacing contacts (Fig. 2).

\subsection{Position of the relevant accessory minerals in the crystallization sequence}

Accessory minerals rich in $\mathrm{Y}+\mathrm{REE}$ (allanite- $(\mathrm{Ce})$, monazite-(Ce), xenotime-(Y), aeschynite- and euxenitegroup minerals, titanite, zircon) are usually less abundant than tourmaline (Škoda et al. 2006, Škoda and Novák 2007). However, these minerals have several orders of magnitude higher concentrations of these elements and may significantly control their contents in the melt.

In the (b) euxenite-type pegmatites rare, minute crystals of allanite-(Ce) occur mostly in narrow, outer granitic unit; allanite-(Ce) was never found in tourmaline-bearing units. In contrast, the $\mathrm{cm}$-sized crystals of allanite-(Ce) or titanite occur in the most evolved, central parts of some tourmaline-free euxenite-type pegmatite dykes of the Třebíč Pluton. Zircon $(<500$ $\mu \mathrm{m})$ is the only accessory mineral associated with, or present as sporadic inclusions in the tourmaline from Pozd'átky and Klučov II. Minerals of aeschynite and euxenite group (Škoda and Novák 2007) are typically present in the most evolved pegmatite units (K-feldspar blocky unit, albite unit) and in most cases crystallized later than tourmaline. 
In the (c) evolved euxenite-type pegmatite Klučov I, mm-sized aeschynite-group minerals as well as small grains $(<500 \mu \mathrm{m})$ of monazite-(Ce), columbite-(Mn) and common cassiterite are present in the graphic unit and/or in the quartz-tourmaline graphic intergrowths; they may have crystallized simultaneously with tourmaline, which also contains inclusions of zircon. Relatively large grains, $\sim 1 \mathrm{~cm}$ in size, of aeschynite-group minerals, cassiterite and herzenbergite were found in the blocky K-feldspar and albitic unit (Škoda and Čopjaková 2005).

In the (d) Kracovice pegmatite, Y,Sc-enriched spessartine and small crystals $(<500 \mu \mathrm{m})$ of monazite-(Ce), xenotime-(Y), cassiterite, zircon, and minerals of columbite and samarskite group occur in the same textural-paragenetic unit as the examined columnar tourmaline (d-Tu1, d-Tu2). All above-mentioned minerals plus fergusonite(Y) rarely appear in the most fractionated inner pegmatite units as smaller than $5 \mathrm{~mm}$ crystals associated with crystals of green fluor-elbaite (not examined in this study). Evidently later, fracture filling allanite-(Ce) is exclusively hosted by the early tourmaline (d-Tu1) (Fig. 2d).

\subsection{Chemical composition of tourmaline - EMP data}

Tourmalines from (b) euxenite-type pegmatites Pozd'átky, Klučov II and Okrašovice show similar chemical composition and compositional evolution (Fig. 3; Tab. 2). Early domains (b-Tu1) correspond to dravite with $\mathrm{Fe}_{\text {tot }} /\left(\mathrm{Fe}_{\text {tot }}+\right.$ $\mathrm{Mg})=0.25-0.39$, moderate Al (5.95-6.14 apfu), high Na (0.71-0.76 apfu), moderate Ca (0.12-0.23 apfu), low Xsite vacancy $(<0.10 \mathrm{pfu})$ and both Ti and $\mathrm{F}(<0.10 \mathrm{apfu})$, whereas later domains of Ca-rich dravite (b-Tu2) show lower Al (5.3-5.93 apfu), higher Ca (0.19-0.43 apfu) and very low X-site vacancy $(<0.04 \mathrm{pfu})$. The contents of $\mathrm{F}$ (0.10-0.19 apfu), Ti (0.21-0.42 apfu) and $\mathrm{Fe}_{\text {tot }} /\left(\mathrm{Fe}_{\text {tot }}+\right.$ $\mathrm{Mg})=0.27-0.44$ are slightly higher. Manganese contents are below the detection limit of EMP (Pozd'átky) or very low (Okrašovice 0.06 wt. \% MnO; Klučov II 0.18 wt. \% MnO).

In the more evolved (c) Klučov I pegmatite, early domains (c-Tu1) are close to schorl end-member composition (Al 5.80-6.05 apfu, Fe 2.87-3.01 apfu) with $\mathrm{Fe}_{\text {tot }} /\left(\mathrm{Fe}_{\text {tot }}+\mathrm{Mg}\right) \sim 0.95$, high Na (0.80-0.89 apfu) low $\mathrm{Ca}(0.10-0.13 \mathrm{apfu})$ and X-site vacancy $(<0.09 \mathrm{pfu})$. Contents of Mn (0.10-0.14 apfu) and F (0.29-0.48 apfu) are higher, while those of Ti (0.09-0.17 apfu) are lower compared to Ca-rich dravite (b-Tu2) from the (b) euxenite-type pegmatites. In the tourmaline rims (c-Tu2), the composition shifts to Al-rich schorl and to Al-rich fluor-schorl (6.43-6.99 apfu Al) but $\mathrm{Fe}_{\text {tot }}\left(\mathrm{Fe}_{\text {tot }}+\mathrm{Mg}\right) \sim$ 0.95 is almost the same. High $\mathrm{X}$-site vacancy $(0.10-0.27$ pfu), low Ca (0.04-0.06 apfu) and higher Mn (0.40-0.46 apfu) with F (0.43-0.57 apfu) are present.

The volumetrically dominant black columnar tourmaline from the Kracovice pegmatite (d-Tu1) corresponds particularly to Al-rich schorl and to very rare Al-rich fluor-schorl (6.92-7.37 apfu Al; 1.96-2.24 apfu Fe; 0.020.08 apfu $\mathrm{Mg} ; \mathrm{Fe}_{\text {tot }} /\left(\mathrm{Fe}_{\text {tot }}+\mathrm{Mg}\right) \sim 0.98 ; 0.19-0.55$ apfu F $)$ with high $\mathrm{X}$-site vacancy (0.28-0.44 pfu). Its composition is similar to the tourmaline (c-Tu2) from the Klučov I pegmatite, but shows higher Al and lower Mn (0.08-0.15 apfu), $\mathrm{Ca}(<0.04 \mathrm{apfu})$ and $\mathrm{Ti}(<0.04 \mathrm{apfu})$, respectively. Later tourmaline $(\mathrm{d}-\mathrm{Tu} 2)$ overgrowing or partly replacing

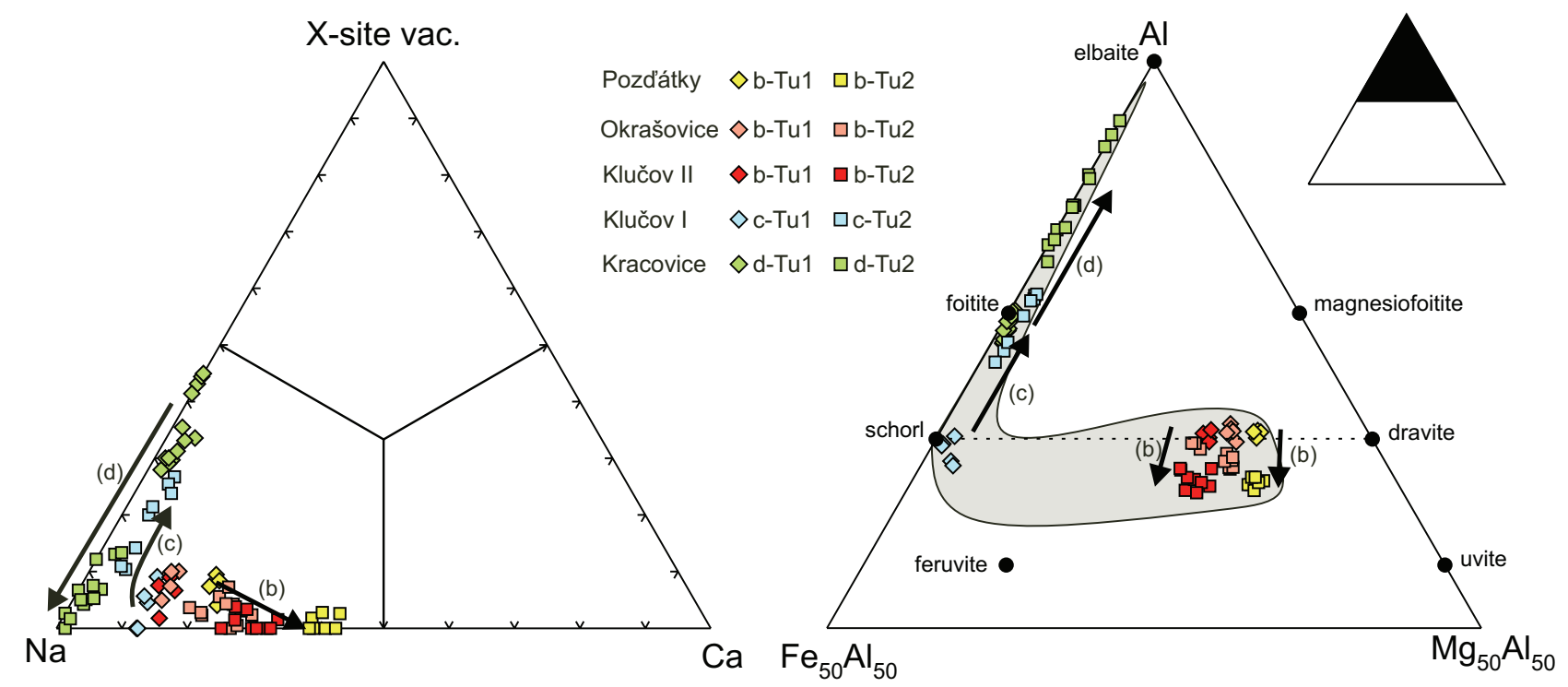

Fig. 3 Chemical composition of tourmaline. a - Occupation of the X-site; $\mathbf{b}-$ Occupation of the $\mathrm{Y}+\mathrm{Z}$ sites. Diamonds - early Tu1 generation; squares - later Tu2 generation. Black arrows - evolutionary trends from early Tu1 to the later Tu2 generation for the (b) euxenite-type pegmatites, (c) Klučov I and (d) Kracovice pegmatites. The grey field outlines the compositions of tourmaline from pegmatites of the Třebíc Pluton after Novák et al. $(2011,2012)$. 


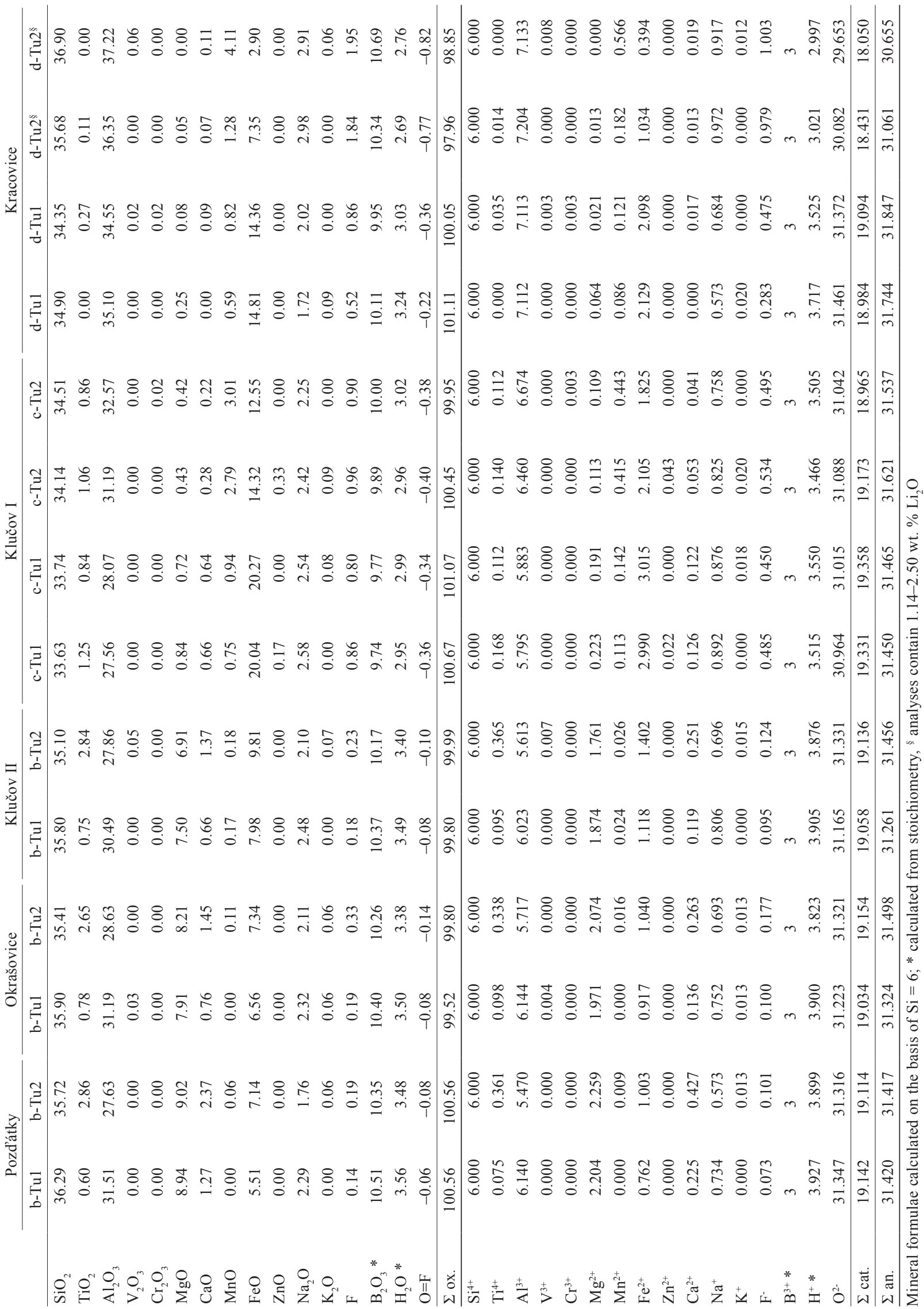


early Al-rich schorl (d-Tu1) corresponds to fluor-schorl to fluor-elbaite (LA-ICP-MS data yields 1.4-2.5 wt. \% $\left.\mathrm{Li}_{2} \mathrm{O}\right)$. Also, high $\mathrm{Al}(6.96-7.32 \mathrm{apfu})$ and $\mathrm{Mn}(0.07-0.57$ apfu), variable $\mathrm{Fe}(0.39-1.45 \mathrm{apfu})$, as well as very low $\mathrm{Mg}\left(<0.06\right.$ apfu; $\left.\mathrm{Fe}_{\text {tot }} /\left(\mathrm{Fe}_{\text {tot }}+\mathrm{Mg}\right) \sim 0.99\right)$ and $\mathrm{Ti}(<$ $0.04 \mathrm{apfu}$ ) contents are typical. The X-site occupancy is characterized by very high $\mathrm{Na}(0.83-0.99 \mathrm{apfu})$, very low $\mathrm{Ca}(<0.03 \mathrm{apfu})$, and $\mathrm{X}$-site vacancy $(<0.13 \mathrm{pfu})$. The content of $\mathrm{F}$ is very high (0.87-1.05 apfu).

Based on the EMP and LA-ICP-MS Li data, dravite occurs exclusively in the (b) euxenite-type pegmatites Pozd'átky, Okrašovice and Klučov II; schorl and fluorschorl in the (c) Klučov I pegmatite, and schorl to rare fluor-schorl and fluor-elbaite in the (d) Kracovice pegmatite. However, presence of significant oxy-tourmaline components (oxy-dravite, oxy-schorl; Novák et al. 2004; Henry et al. 2011; Bačík et al. 2013) in tourmalines is supported by high $\mathrm{Al}$ (up to $7.4 \mathrm{apfu}$ ) contents in tourmalines from the Klučov I and Kracovice pegmatites, and the moderate contents of $\mathrm{Fe}^{3+}$ (Novák et al. 2011) in the euxenite-type pegmatites (17-26\%), as well as in the Klučov I pegmatite (22 \%).

\subsection{Concentrations of $Y+R E E$ and other trace elements in tourmalines - LA-ICP- -MS data}

The tourmalines from the pegmatites in the Třebič Pluton are generally characterized by variable and relatively high Y + REE concentrations of 4-458 ppm (Tab. 3). All tourmaline grains show enrichment in LREE, with $\mathrm{Ce}$ being the most abundant element. The chondritenormalized patterns decrease uniformly from $\mathrm{La}$ to $\mathrm{Tb}$, the elements between $\mathrm{Tb}$ and $\mathrm{Tm}$ are often below the detection limit (Tab. 3), and then follows an increase in $\mathrm{Yb}$ and $\mathrm{Lu}$ (Fig. $4 \mathrm{a}-\mathrm{e}$ ). The total $\mathrm{Y}+\mathrm{REE}$ concentrations, $\mathrm{La}_{\mathrm{N}} / \mathrm{Yb}_{\mathrm{N}}$ ratios and Eu/Eu* vary significantly depending on the tourmaline generation and host pegmatite.

\subsubsection{Yttrium + REE in dravitic tourmaline from the (b) euxenite-type pegmatites}

In general, early dravite (b-Tu1) is Y + REE-poor with flatter Y + REE patterns compared with later Ca-rich dravite (b-Tu2). The tourmaline from the Pozd'átky pegmatite shows the lowest $Y+R E E$ contents (11-15 ppm in b-Tu1; 30-112 ppm in b-Tu2) as well as the flattest Y + REE patterns (avg. $\mathrm{La}_{\mathrm{N}} / \mathrm{Gd}_{\mathrm{N}} \sim 48$ in b-Tu1; avg. $\mathrm{La}_{\mathrm{N}} / \mathrm{Gd}_{\mathrm{N}}$ $\sim 61$ in b-Tu2) with pronounced positive Eu anomalies $\left(\mathrm{Eu} / \mathrm{Eu}^{*}=10-27\right.$; avg. $\left.\mathrm{Eu} / \mathrm{Eu}^{*}=16\right)$. Tourmalines from the Okrašovice pegmatite have higher $\Sigma Y+$ REE (16-31 ppm in b-Tu1; 45-146 ppm in b-Tu2) with steeper, more LREE-enriched $\mathrm{Y}+\mathrm{REE}$ patterns $\left(\right.$ avg. $\mathrm{La}_{\mathrm{N}} / \mathrm{Gd}_{\mathrm{N}} \sim 54$ in
b-Tu1, and avg. $\mathrm{La}_{\mathrm{N}} / \mathrm{Gd}_{\mathrm{N}} \sim 180$ in b-Tu2). Commonly, they show weak positive Eu anomalies $\left(\mathrm{Eu} / \mathrm{Eu}^{*}=1.0\right.$ 4.5). Whereas, locally the tourmalines intergrowing with large $\mathrm{K}$-feldspars show slightly negative Eu anomalies $\left.\mathrm{Eu} / \mathrm{Eu}^{*}=0.7-1.0\right)$. Tourmalines from the Klučov II pegmatite exhibit the highest $\Sigma Y+$ REE (19-125 ppm in b-Tu1; 67-218 ppm in b-Tu2) with steep LREE-enriched $\mathrm{Y}+$ REE patterns (avg. $\mathrm{La}_{\mathrm{N}} / \mathrm{Gd}_{\mathrm{N}} \sim 57$ in b-Tu1 and avg. $\mathrm{La}_{\mathrm{N}} / \mathrm{Gd}_{\mathrm{N}} \sim 140$ in $\left.\mathrm{b}-\mathrm{Tu} 2\right)$, and without significant $\mathrm{Eu}$ anomalies $\left(\mathrm{Eu} / \mathrm{Eu}^{*}=0.3-4.6\right.$; avg. $\left.\mathrm{Eu} / \mathrm{Eu}^{*}=1.3\right)$.

\subsubsection{Yttrium + REE in schorl, fluor-schorl and fluor-elbaite from the (c) Klučov I and (d) Kracovice pegmatites}

The concentrations of $Y+R E E$ in tourmalines from the Klučov I pegmatite are higher in early schorl (c-Tu1) ( $\Sigma \mathrm{Y}$ $+\mathrm{REE}=25-69 \mathrm{ppm}$ ), and systematically decrease from core to rim. Later overgrowths of Al-rich schorl (c-Tu2) overgrowing schorl (c-Tu1) show even lower $\Sigma$ Y + REE (14-28 ppm). Both tourmaline types have steep LREEenriched $\mathrm{Y}+\mathrm{REE}$ patterns (avg. $\mathrm{La}_{\mathrm{N}} / \mathrm{Gd}_{\mathrm{N}} \sim 120$; avg. $\mathrm{La}_{\mathrm{N}} / \mathrm{Gd}_{\mathrm{N}} \sim 86$ ) with strongly negative Eu anomalies (Eu is below the detection limit; $<0.02 \mathrm{ppm}$ ). The chondritenormalized patterns seem to be flatter with decreasing $\Sigma Y$ + REE contents.

The Y + REE contents in volumetrically dominant Al-rich schorl (d-Tu1) from the (d) Kracovice pegmatite vary significantly from $17-458 \mathrm{ppm}$ with steep LREEenriched $\mathrm{Y}+\mathrm{REE}$ patterns $\left(\mathrm{La}_{\mathrm{N}} / \mathrm{Gd}_{\mathrm{N}}\right.$ ratio 10-29). Later overgrowths of fluor-elbaite (d-Tu2) are strongly depleted in $\mathrm{Y}+\mathrm{REE}(4-31 \mathrm{ppm}$ ) with flatter Y + REE patterns $\left(\mathrm{La}_{\mathrm{N}} / \mathrm{Gd}_{\mathrm{N}}\right.$ ratio 3-12). Both tourmaline types show deep negative $\mathrm{Eu}$ anomalies $\left(\mathrm{Eu} / \mathrm{Eu}^{*}<0.05\right)$, Eu is commonly below the detection limit.

\subsubsection{Scandium contents in tourmalines}

The contents of Sc are relatively high, vary significantly and generally positively correlate with $\sum \mathrm{Y}+\mathrm{REE}$ (Tab. 3; Fig. 5a). In the (b) euxenite-type pegmatites, the Pozd'átky pegmatite has tourmaline with the lowest Sc contents (28-92 ppm), whereas tourmaline from the Okrašovice pegmatite shows the highest $\mathrm{Sc}$ contents (145-765 ppm; avg. $455 \mathrm{ppm}$ ). The concentrations of

Fig. 4 The $Y+$ REE patterns of tourmaline (a-e) normalized by chondrite (McDonough and Sun 1995). a - Pozd'átky pegmatite; b Okrašovice pegmatite; $\mathbf{c}$ - Klučov II pegmatite; $\mathbf{d}$ - Klučov I pegmatite; e - Kracovice pegmatite. Solid line - field of Tu1 generation; dashed line - field of Tu2 generation; grey area - bellow the detection limit of LA-ICP-MS; f - Y + REE patterns of tourmaline-bearing euxenitetype pegmatites. 
a)

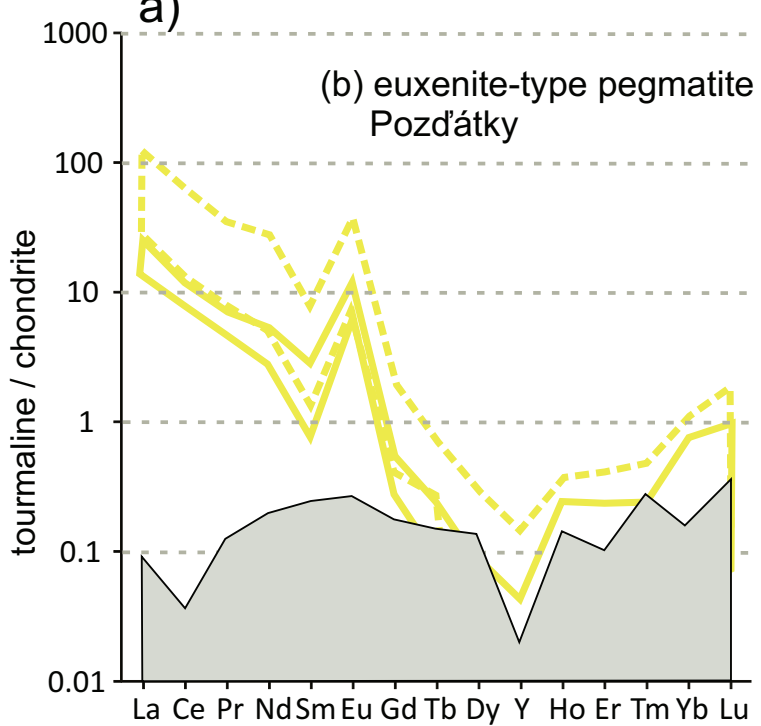
b)
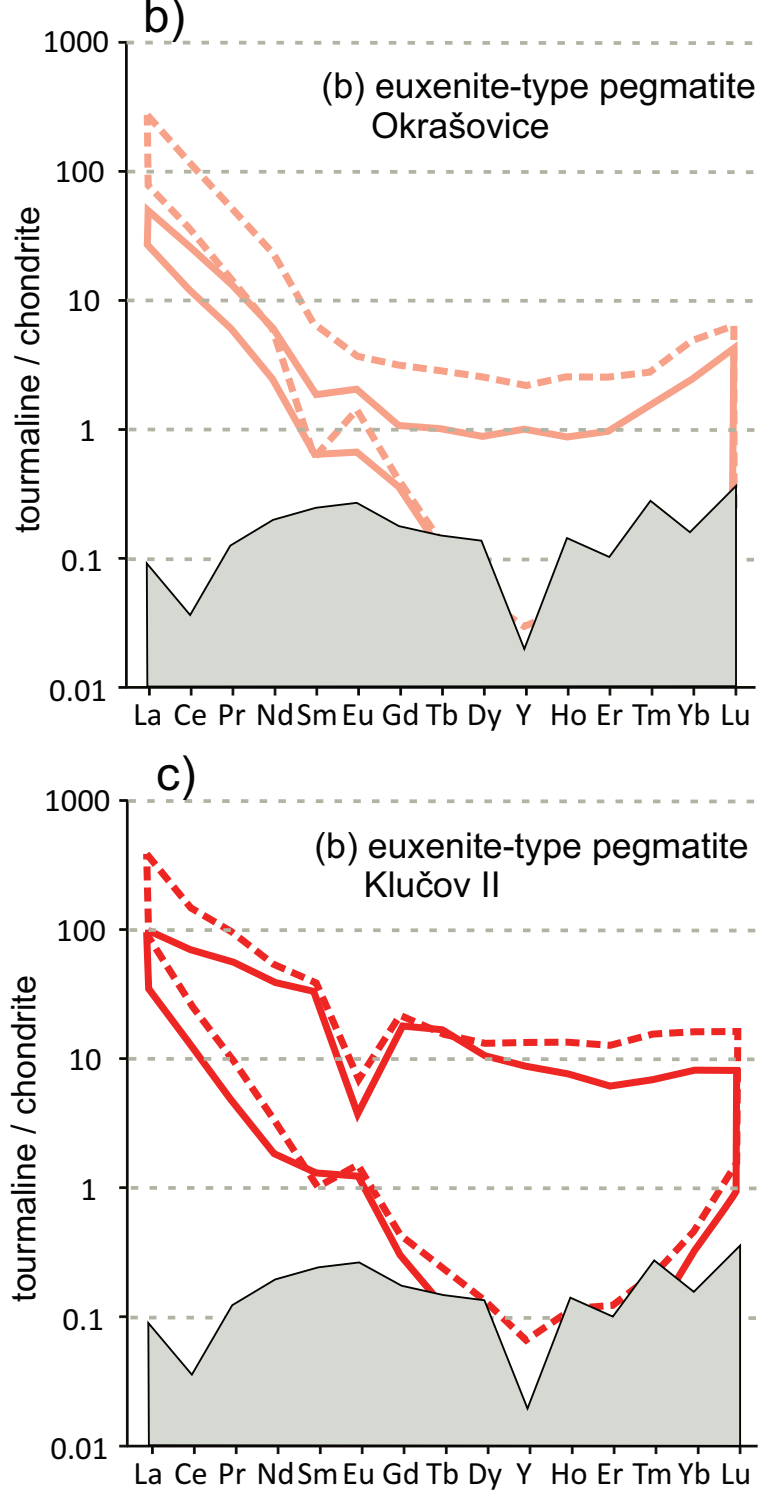

d)

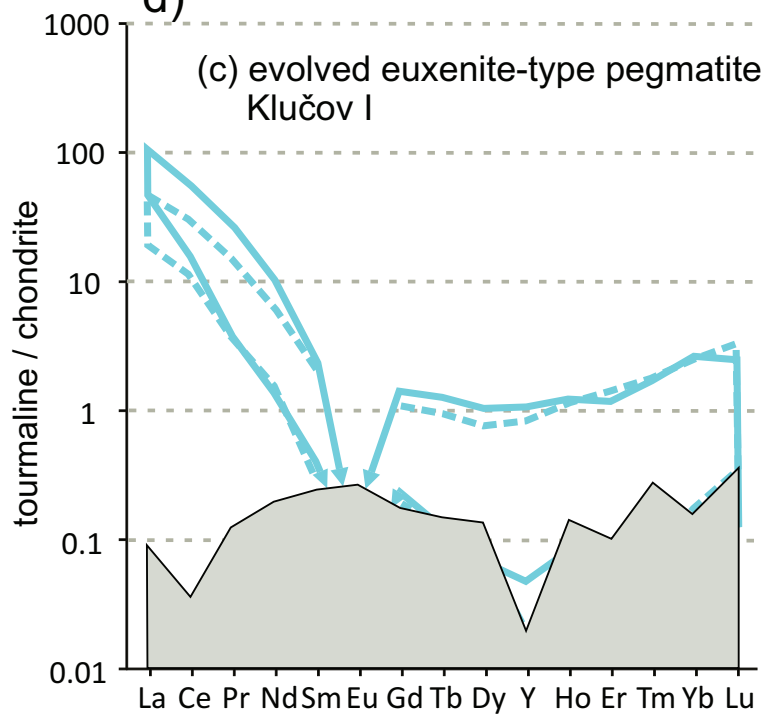

e)
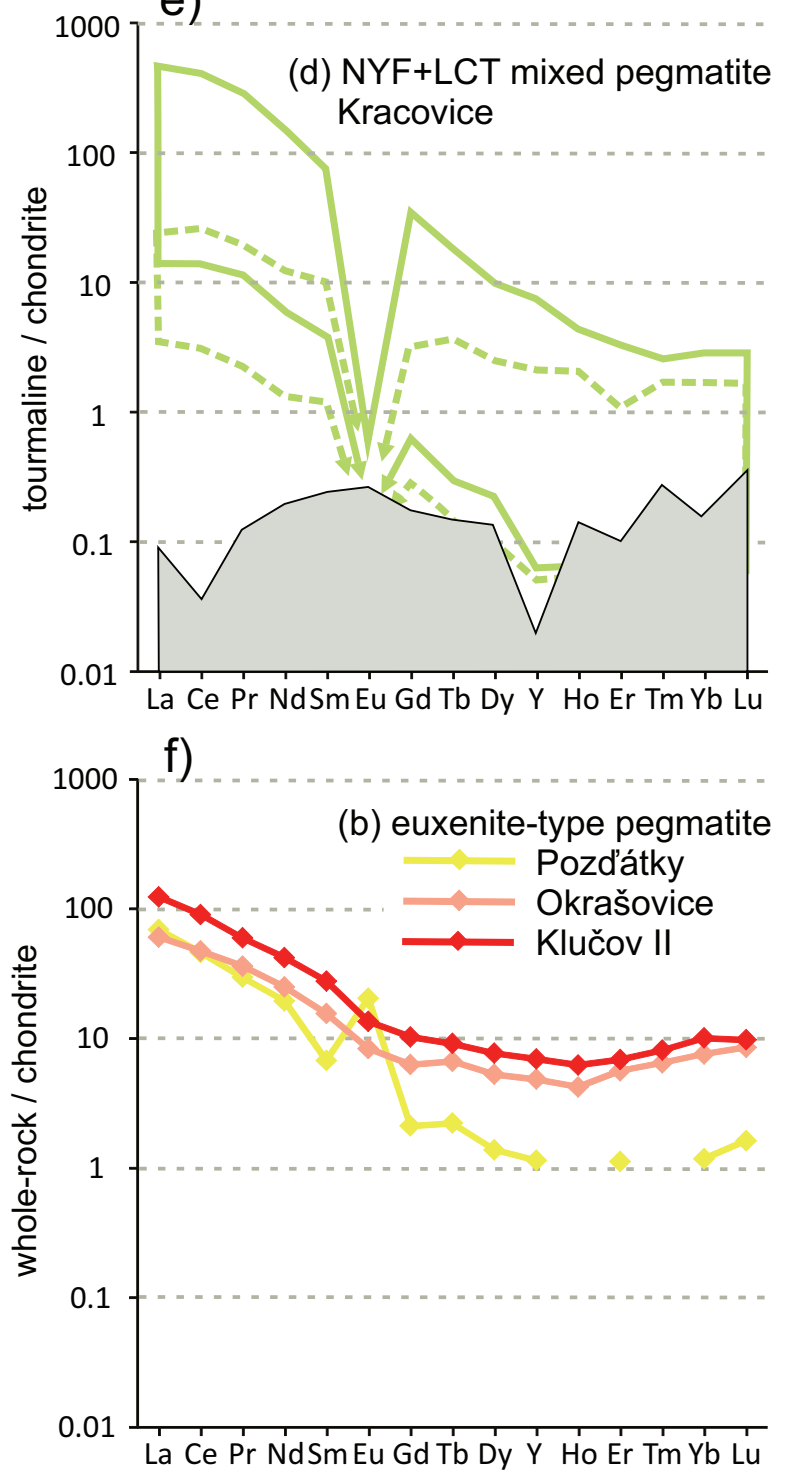
Оิ|

馬



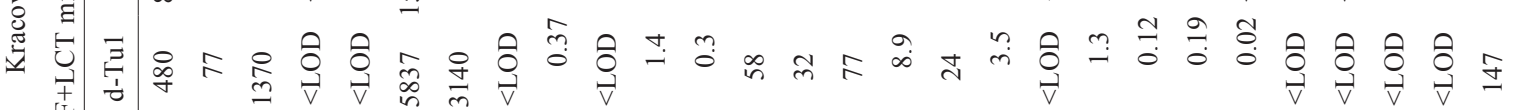

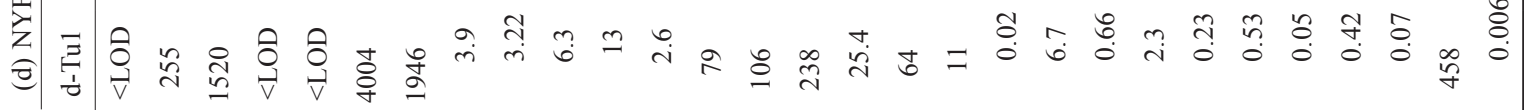

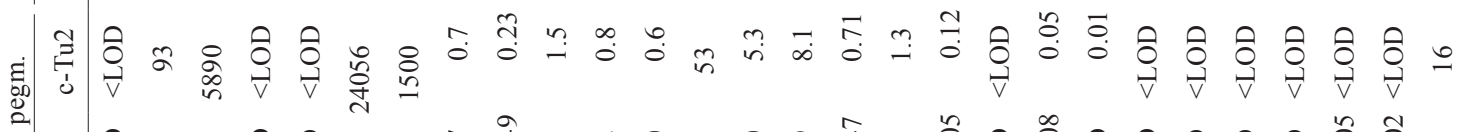

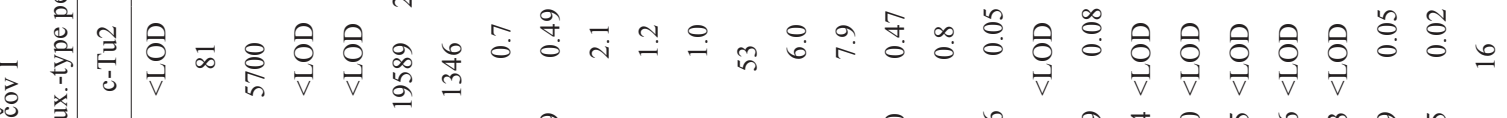

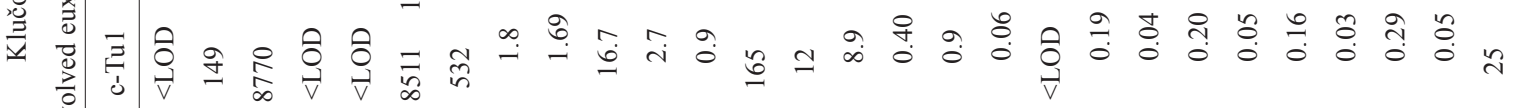

仓

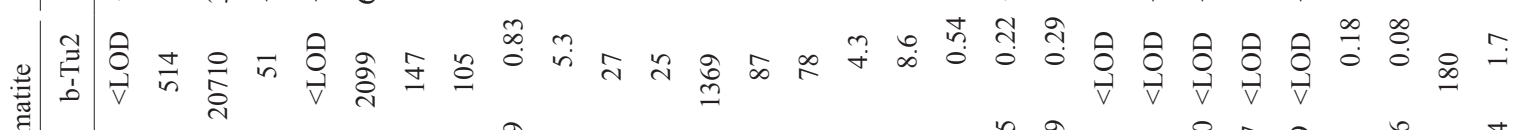

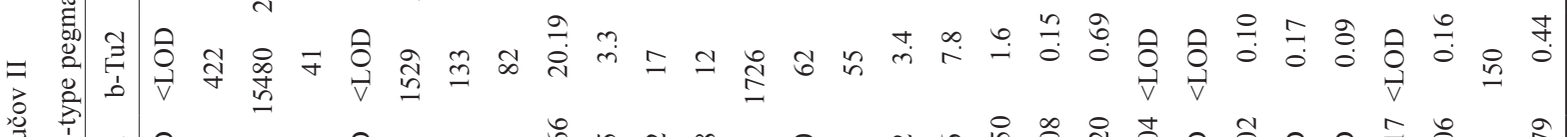

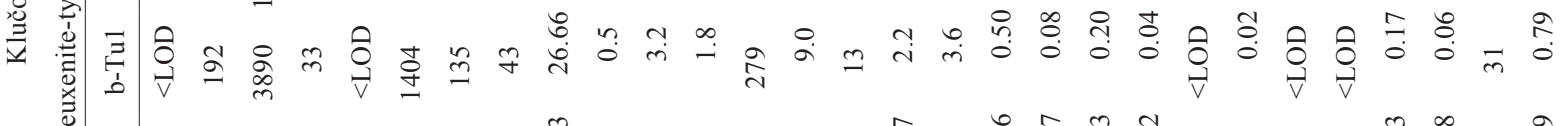

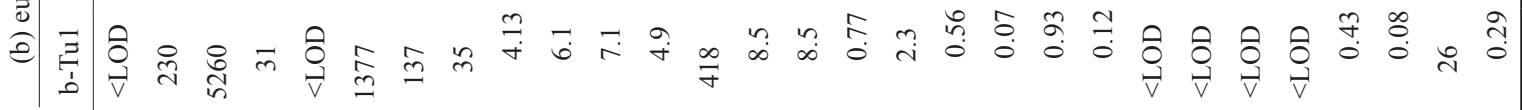

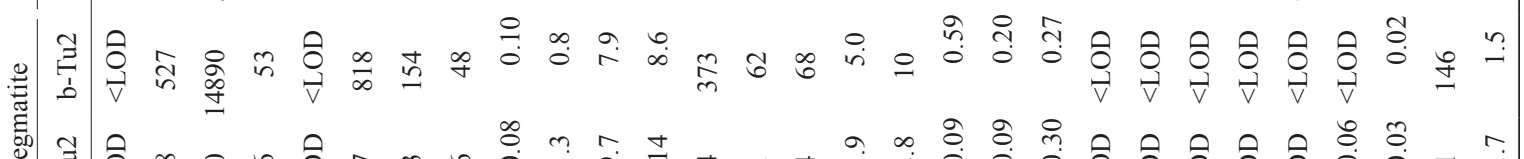

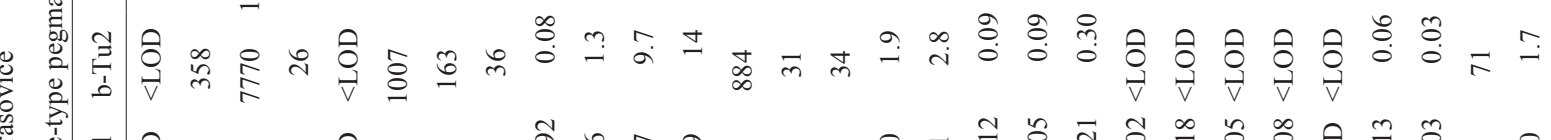

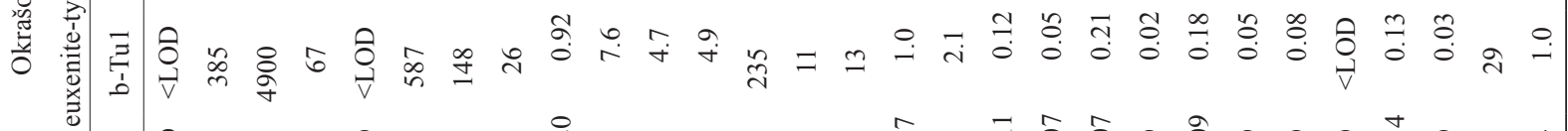

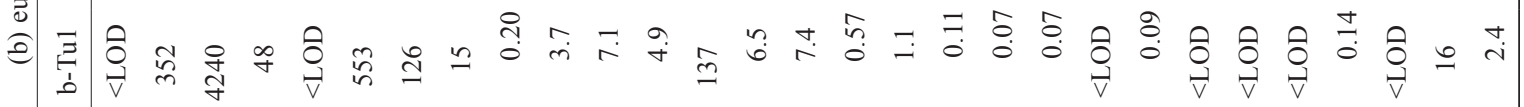

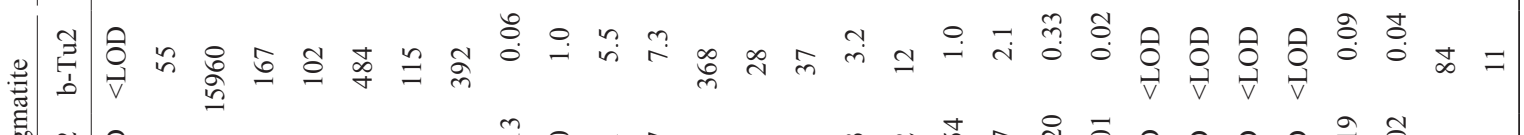

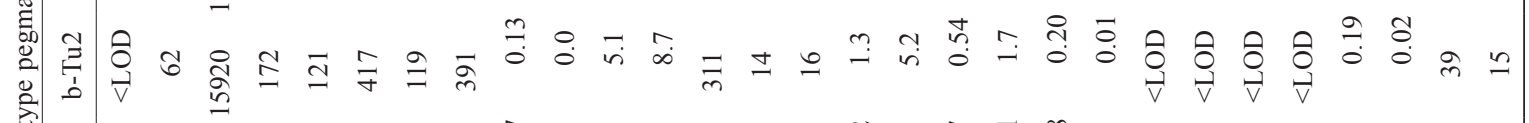

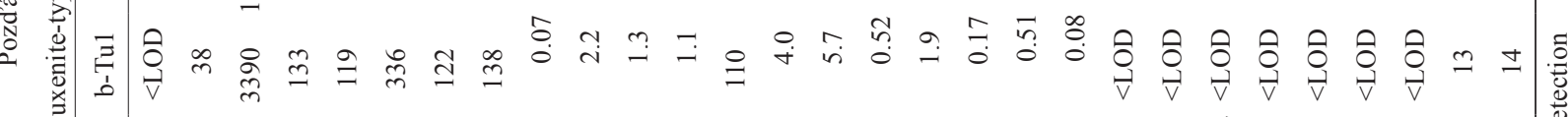

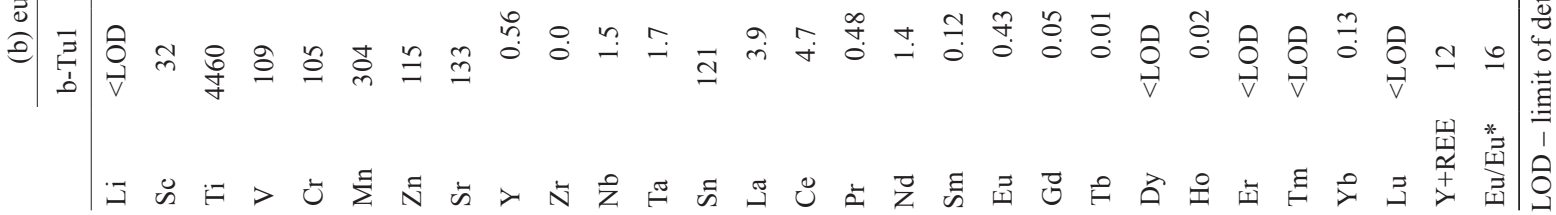



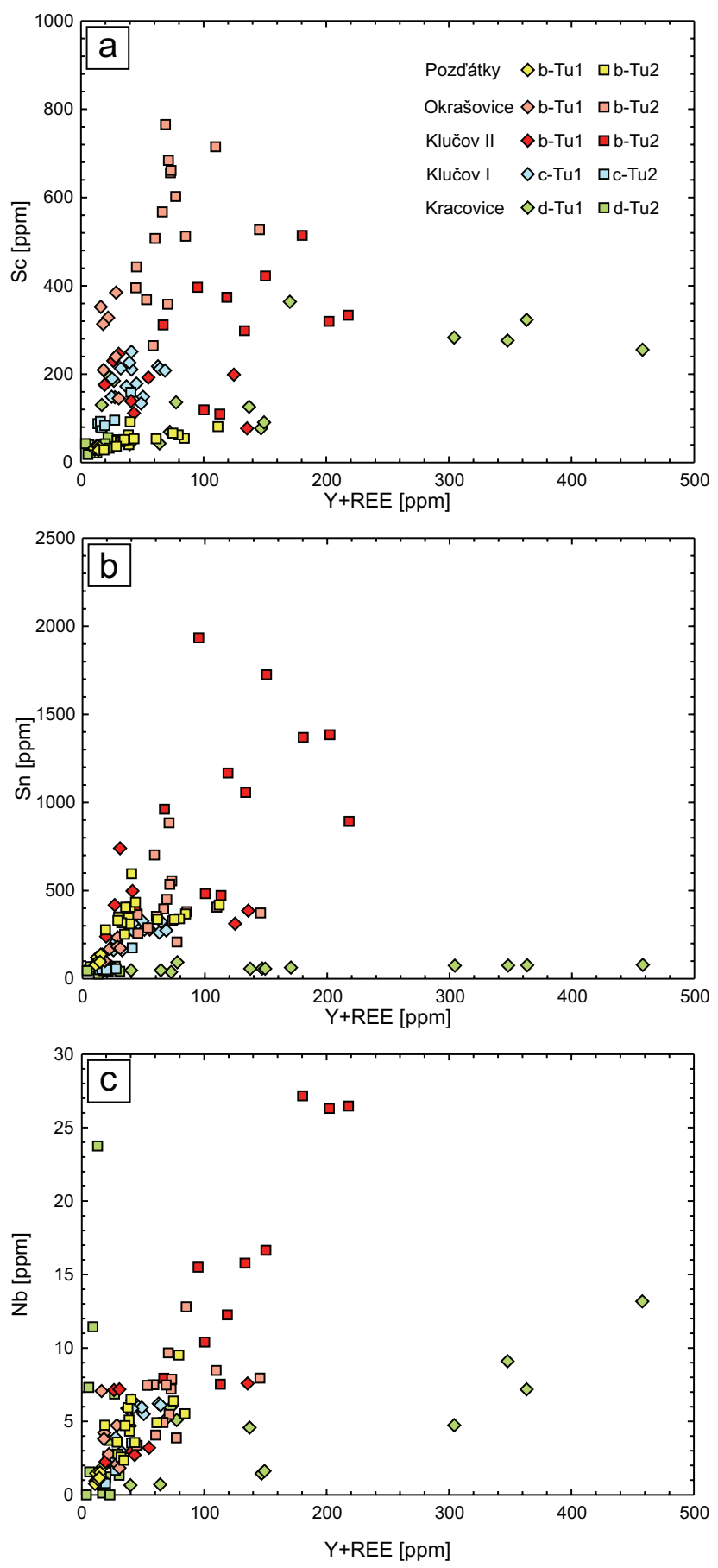

Fig. 5 Evolution of the trace elements (LA-ICP-MS data) during the tourmaline growth demonstrated on the binary plots of: Sc vs. Y + REE (a); Sn vs. Y + REE (b); Nb vs. Y + REE (c). The plotting symbols are the same as in Fig. 3.

Sc increase systematically from early dravite (b-Tu1) to later Ca-rich dravite (b-Tu2) at all localities. Tourmalines from the (c) Klučov I and (d) Kracovice pegmatites show high and variable concentrations of Sc (78-251 ppm and 18-364 ppm, respectively). The evolutionary trend is opposite than in the (b) euxenite-type pegmatites; the Sc decreases from early schorl (c-Tu1) and Al-rich schorl (d-Tu1) to later Al-rich schorl (c-Tu2) and fluor-elbaite (d-Tu2), respectively.

\subsubsection{Other trace elements in tourmalines}

Along with $\mathrm{Y}+\mathrm{REE}$ and Sc, behavior of other trace elements (mainly $\mathrm{Sn}, \mathrm{Nb}$ and $\mathrm{Zr}$; Tab. 3; Fig. 5b-c) in tourmalines was examined to recognize the effect of crystallization of the associated accessory minerals on the contents of trace elements in tourmalines. The concentrations of $\mathrm{Sn}$ are high mainly in tourmalines from the (b) euxenite-type pegmatites and generally increase from early dravite (b-Tu1) to Ca-rich dravite (b-Tu2): Pozd'átky (80-140 ppm; 250-600 ppm) $\rightarrow$ Okrašovice (140-235 ppm; 210-885 ppm) $\rightarrow$ Klučov II (240-740 ppm; 890-1935 ppm), respectively. In the (c) Klučov I pegmatite, the contents of Sn decrease from schorl (c-Tu1, 162-327 ppm) to Al-rich schorl (c-Tu2, 46-59 ppm). Rather low contents of $\mathrm{Sn}$ were recorded in the Al-rich schorl (d-Tu1, 38-94 ppm) and fluor-elbaite (d-Tu2, 26-73 ppm) at the (d) Kracovice pegmatite.

Niobium contents in tourmalines are usually less than $30 \mathrm{ppm}$, but trends similar to REE and Sc were observed (Fig. 5c). The contents of $\mathrm{Nb}$ increase from dravite (b-Tu1) to Ca-rich dravite (b-Tu2) and in the (b) euxenite-type pegmatites: Pozd'átky (avg. $3.5 \mathrm{ppm}) \rightarrow$ Okrašovice (avg. $5.8 \mathrm{ppm}) \rightarrow$ Klučov II (avg. $16 \mathrm{ppm}$ ). In the (c) Klučov I pegmatite, the $\mathrm{Nb}$ contents decrease from schorl (c-Tu1) with 2.2-6.4 ppm Nb to Al-rich schorl (c-Tu2) with $1.0 \mathrm{ppm} \mathrm{Nb}$ on average. In (d) the Kracovice pegmatite, $\mathrm{Nb}$ concentrations vary from $<1$ to $13 \mathrm{ppm}$ in both tourmaline generations (d-Tu1) and (d-Tu2). Zirconium in tourmalines is generally very low, commonly under $7 \mathrm{ppm}$ (avg. $1.7 \mathrm{ppm}$ ), and no welldefined evolution trend was observed.

\subsection{Whole-rock chemistry}

Whole-rock chemical compositions of tourmaline-bearing units from the (b) euxenite-type pegmatites are given in Tab. 4. The rocks are felsic $\left(\mathrm{SiO}_{2} \sim 76\right.$ wt. \%), with low $\mathrm{Fe}_{2} \mathrm{O}_{3}(0.3-0.4$ wt. \%) and $\mathrm{MgO}(0.07-0.24$ wt. \%). The ASI (defined as atomic ratio $\mathrm{Al} /(2 \mathrm{Ca}+\mathrm{Na}+\mathrm{K})=1.02$ 1.09) indicates a subaluminous character. They contain high concentrations of $\mathrm{K}_{2} \mathrm{O}$ (6.2-7.5 wt. \%), $\mathrm{Rb}(222-297$ ppm), U (4-29 ppm) and Th (15-32 ppm) comparable to the composition of their parental granites (melanocratic syenite-granite of the Třebíc Pluton). Low concentrations of $\mathrm{MnO}\left(<0.02\right.$ wt. \%) and $\mathrm{Cr}_{2} \mathrm{O}_{3}(<0.002$ wt. \%) are typical as are very low $\mathrm{P}_{2} \mathrm{O}_{5}(<0.02$ wt. \%), which is in contrast to the parental syenite-granite with $\mathrm{P}_{2} \mathrm{O}_{5}$ $0.45-0.98$ wt. \%. The pegmatites exhibit variation in $\sum Y$ + REE contents (61-133 ppm; Pozd'átky < Okrašovice < 
Tab. 4 Representative whole-rock chemical compositions of the (b) euxenite-type pegmatites

\begin{tabular}{|c|c|c|c|c|}
\hline & LOD & Pozd'átky & Okrašovice & Klučov II \\
\hline $\mathrm{SiO}_{2}$ & 0.01 & 76.15 & 76.51 & 75.74 \\
\hline $\mathrm{TiO}_{2}$ & 0.01 & 0.05 & 0.05 & 0.05 \\
\hline $\mathrm{Al}_{2} \mathrm{O}_{3}$ & 0.01 & 13.06 & 13.08 & 13.04 \\
\hline $\mathrm{Fe}_{2} \mathrm{O}_{3}$ & 0.04 & 0.36 & 0.33 & 0.39 \\
\hline $\mathrm{Cr}_{2} \mathrm{O}_{3}$ & 0.001 & 0.001 & $<0.001$ & 0.002 \\
\hline $\mathrm{MnO}$ & 0.01 & 0.01 & 0.01 & 0.02 \\
\hline $\mathrm{MgO}$ & 0.01 & 0.24 & 0.11 & 0.07 \\
\hline $\mathrm{CaO}$ & 0.01 & 0.24 & 0.78 & 0.11 \\
\hline $\mathrm{Na}_{2} \mathrm{O}$ & 0.01 & 2.94 & 3.25 & 2.55 \\
\hline $\mathrm{K}_{2} \mathrm{O}$ & 0.01 & 6.24 & 5.58 & 7.46 \\
\hline $\mathrm{P}_{2} \mathrm{O}_{5}$ & 0.01 & 0.02 & 0.02 & 0.01 \\
\hline Total & & 99.91 & 100.02 & 99.83 \\
\hline LOI & & 0.6 & 0.3 & 0.4 \\
\hline TOT/C & 0.02 & 0.02 & 0.02 & 0.02 \\
\hline TOT/S & 0.01 & $<0.01$ & 0.01 & 0.01 \\
\hline ASI & & 1.09 & 1.02 & 1.05 \\
\hline $\mathrm{FeO}_{\mathrm{tot}} /\left(\mathrm{FeO}_{\mathrm{tot}}+\mathrm{MgO}\right)$ & & 0.57 & 0.73 & 0.83 \\
\hline $\mathrm{Be}$ & 1 & 11 & 42 & 11 \\
\hline $\mathrm{F}$ & 10 & 110 & 90 & na \\
\hline B & 3 & 24 & 68 & na \\
\hline $\mathrm{Ba}$ & 1 & 964 & 197 & 405 \\
\hline $\mathrm{Rb}$ & 0.1 & 222 & 279 & 297 \\
\hline $\mathrm{Sr}$ & 0.5 & 348 & 125 & 186 \\
\hline V & 5 & $<5$ & $<5$ & $<5$ \\
\hline $\mathrm{Sn}$ & 1 & 2 & 5 & 4 \\
\hline $\mathrm{U}$ & 0.1 & 3.5 & 10.7 & 28.6 \\
\hline $\mathrm{Nb}$ & 0.1 & 3.7 & 19.0 & 23.3 \\
\hline $\mathrm{Zr}$ & 0.1 & 23.8 & 59.9 & 57.0 \\
\hline $\mathrm{Th}$ & 0.2 & 15.4 & 24.7 & 31.6 \\
\hline $\mathrm{Ta}$ & 0.1 & 0.9 & 7.3 & 4.7 \\
\hline Hf & 0.1 & 1.7 & 4.3 & 3.5 \\
\hline $\mathrm{Sc}$ & 1 & $<1$ & 1 & 1 \\
\hline $\bar{Y}$ & 0.1 & 1.8 & 7.6 & 10.9 \\
\hline $\mathrm{La}$ & 0.1 & 16.4 & 14.3 & 29.3 \\
\hline $\mathrm{Ce}$ & 0.1 & 28.2 & 28.9 & 55.3 \\
\hline $\operatorname{Pr}$ & 0.02 & 2.75 & 3.35 & 5.53 \\
\hline $\mathrm{Nd}$ & 0.3 & 8.9 & 11.4 & 19.2 \\
\hline $\mathrm{Sm}$ & 0.05 & 1.0 & 2.3 & 4.1 \\
\hline $\mathrm{Eu}$ & 0.02 & 1.15 & 0.47 & 0.76 \\
\hline $\mathrm{Gd}$ & 0.05 & 0.42 & 1.25 & 2.04 \\
\hline $\mathrm{Tb}$ & 0.01 & 0.08 & 0.24 & 0.33 \\
\hline Dy & 0.05 & 0.34 & 1.30 & 1.89 \\
\hline Но & 0.02 & $<0.02$ & 0.23 & 0.34 \\
\hline $\mathrm{Er}$ & 0.03 & 0.18 & 0.90 & 1.10 \\
\hline $\mathrm{Tm}$ & 0.01 & $<0.01$ & 0.16 & 0.20 \\
\hline $\mathrm{Yb}$ & 0.05 & 0.19 & 1.22 & 1.62 \\
\hline $\mathrm{Lu}$ & 0.01 & 0.04 & 0.21 & 0.24 \\
\hline$\Sigma \mathrm{Y}+\mathrm{REE}$ & & 61 & 74 & 133 \\
\hline $\mathrm{Eu} / \mathrm{Eu}^{*}$ & & 5.41 & 0.84 & 0.80 \\
\hline
\end{tabular}

LOD - limit of detection
Klučov II). The chondrite-normalized plots of Y + REE concentrations (Fig. 4f) display general enrichment in LREE with steeply decreasing pattern from La to Ho, followed by an upturn from Ho to Lu. The Pozd'átky pegmatite shows a positive $\mathrm{Eu}$ anomaly $\left(\mathrm{Eu} / \mathrm{Eu}^{*}=5.4\right)$, while the Okrašovice and Klučov II pegmatites display inconspicuous negative Eu anomalies (Eu/Eu* 0.8), respectively. The contents of Sc are very low ( $\leq 1 \mathrm{ppm})$ in all samples in contrast to the parental syenite-granite with 9-27 ppm Sc.

\section{Discussion}

Tourmalines crystallize directly from melt or from the B-rich hydrothermal fluids during magmatic-hydrothermal transition in granitic systems (e.g., London et al. 1996; Jiang et al. 2008). The compositional trends (evolution of $\mathrm{Fe}_{\text {tot }} /\left(\mathrm{Fe}_{\text {tot }}+\mathrm{Mg}\right)$ ratio and $\mathrm{Mn}$ and $\mathrm{F}$ abundances $)$ with textural relations to associated minerals suggest that almost all paragenetic and textural types of tourmaline investigated in the current study are considered to have crystallized from a melt, with the exception of late overgrowths of fluor-elbaite (d-Tu2), at least in part replacing early Al-rich schorl (d-Tu1). This tourmaline might be of a metasomatic-hydrothermal origin.

\subsection{Compositional evolution of tourmalines (EMPA data)}

Concentrations of selected major and minor elements, mainly $\mathrm{Mn}$ and $\mathrm{Fe}_{\text {tot }} /\left(\mathrm{Fe}_{\text {tot }}+\mathrm{Mg}\right)$ ratios, are frequently used as indicators of the degree of fractionation in tourmalines (e.g., Jolliff et al. 1986; Selway et al. 1999; Novák et al. 2011). Most tourmaline compositions from the NYF pegmatites of the Třebíc Pluton fall into the $\mathrm{Fe}_{\text {tot }} /\left(\mathrm{Fe}_{\text {tot }}+\mathrm{Mg}\right)$ range of $0.2-0.5$ and low Al range of 5.0-6.0 apfu; such primitive tourmaline compositions are rather uncommon in granitic pegmatites (Novák et al. 2011). Tourmaline from the (b) euxenite-type Pozd'átky, Okrašovice and Klučov II pegmatites falls into the same field (Fig. 3b). The evolution from early dravite (b-Tu1) to Ca-rich dravite (b-Tu2), and increase in $\mathrm{Fe}_{\text {tot }} /\left(\mathrm{Fe}_{\text {tot }}\right.$ $+\mathrm{Mg}), \mathrm{Ca}, \mathrm{F}, \mathrm{Mn}, \mathrm{Ti}$, and decrease in Al are typical. Positive correlations of $\mathrm{Fe}_{\text {tot }} /\left(\mathrm{Fe}_{\text {tot }}+\mathrm{Mg}\right)$ and $\mathrm{F}$ with $\mathrm{Mn}$ (Selway et al. 1999) reflect increasing degree of fractionation (Fig. 6). However, increase in $\mathrm{Ca}$ and decrease in Al from dravite (b-Tu1) to Ca-rich dravite (b-Tu2) in the (b) euxenite-type pegmatites via the uvite substitution $\mathrm{NaAl}\left(\mathrm{CaR}^{2+}\right)_{-1}$ imply crystallization of tourmaline from an Al-depleted (metaluminous) melt. Such trend is very unusual at a magmatic stage of granitic pegmatites where increase in Al during fractionation is characteristic (e.g., Jolliff et al. 1986; Morgan and London 1999; Selway et 

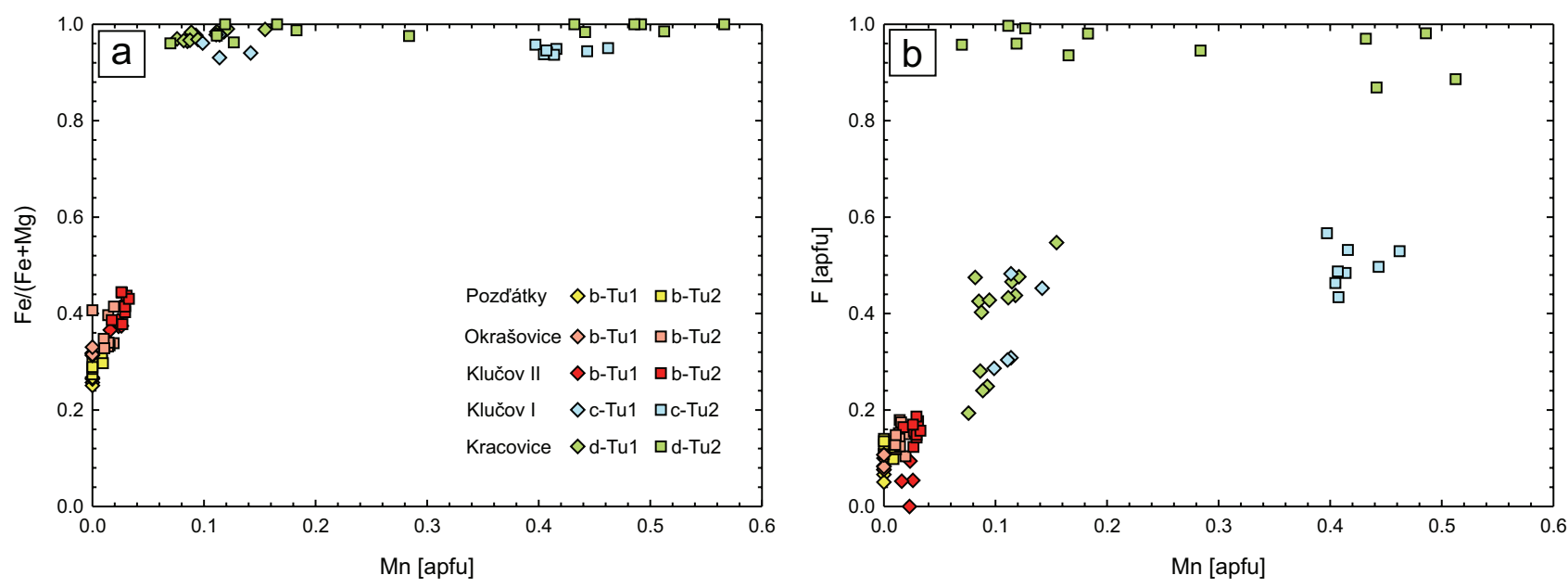

Fig. 6 Variations of the major and minor elements in tourmaline based on EMP data: $\mathrm{Fe}_{\mathrm{tot}}\left(\mathrm{Fe}_{\mathrm{tot}}+\mathrm{Mg}\right)$ vs. Mn (a); F vs. Mn (b). The plotting symbols are the same as in Fig. 3.

al. 1999). The $\mathrm{Fe}_{\text {tot }} /\left(\mathrm{Fe}_{\text {tot }}+\mathrm{Mg}\right)$ ratios in tourmaline from the (b) euxenite-type pegmatites Pozd'átky, Okrašovice and Klučov II $(0.25-0.31<0.32-0.41<0.37-0.44$, respectively), increase in the same order as $\mathrm{FeO} /(\mathrm{FeO}$ $+\mathrm{MgO})$ in the whole-rock analyses do $(0.57<0.73<$ 0.83; Tab. 4).

The apparent increase in $\mathrm{Fe}_{\text {tot }} /\left(\mathrm{Fe}_{\text {tot }}+\mathrm{Mg}\right)$, and elevated contents of $\mathrm{Mn}$ and $\mathrm{F}$ in tourmaline from the (c) Klučov I pegmatite (Fig. 6) showing evolution from schorl (c-Tu1) to Al-rich schorl (c-Tu2) demonstrate that it represents the most evolved euxenite-type pegmatite of the Třebíč Pluton (see also Novák et al. 2011, 2012). The (d) mixed (NYF + LCT) Kracovice pegmatite with tourmaline evolution from Al-rich schorl (d-Tu1) to Mn-rich fluor-elbaite (d-Tu2) indicates its formation from the most fractionated F,Li,B-enriched melt in the pegmatites generated by the Třebíč Pluton (Novák et al. 2012). These trends are, in general, similar to the primary (magmatic) evolution of tourmaline in ordinary, peraluminous, lepidolite-subtype pegmatites (e.g., Jolliff et al. 1986, Selway et al. 1999; Novák 2000). Late rims of fluor-elbaite (d-Tu2) showing irregular contacts and replacement features (Fig. 2d) are likely metasomatichydrothermal. A similar chemical feature was seen in the replacement magmatic-hydrothermal tourmaline fibers of the Cruzeiro pegmatite (Dutrow and Henry 2000).

\subsection{Concentration of $Y+R E E$ and Sc in tourmalines}

Distributions of $\mathrm{Y}+\mathrm{REE}$ in tourmalines from various geological settings are controlled mainly by the total contents of REE in local rock reservoirs (granitic melt; sedimentary precursor; Torres-Ruiz et al. 2003; Raith et al. 2004), and/or by the composition of hydrothermal fluids (King et al. 1988; Jiang et al. 2004; Garda et al.
2010; Čopjaková et al. 2013). However, the role of associated Y,REE-rich accessory minerals has not been studied.

The contents of $\mathrm{Y}+\mathrm{REE}$ in tourmalines from granitic pegmatites are generally low, less than 30 ppm (Jolliff et al. 1987; Hellingwerf et al. 1994; Roda et al. 1995; Kontak et al. 2002). The concentrations of $Y+R E E$ in pegmatites of the Třebíč Pluton are among the highest (up $457 \mathrm{ppm}$ ) reported to date. Extraordinary REE-enriched dravite from granitic pegmatite Forshammar (Sweden) attains 100-1200 ppm इREE (Bačík et al. 2012). Both occurrences represent tourmaline formation in relatively primitive pegmatites with NYF or mixed (NYF + LCT) signatures. Elbaite from the mixed (LCT + NYF) pegmatite Anjanabonoina (Madagascar) shows $150 \mathrm{ppm}$ REE (Ertl et al. 2006), and tourmaline from the Haksberg and Riddarhyttan pegmatites (Sweden) contains 100 ppm EREE (Hellingwerf et al. 1994).

Based on the published data, the absence of any characteristic REE pattern for tourmaline is evident (e.g., King et al. 1988; Yavuz et al. 1999; Torres-Ruiz et al. 2003; Raith et al. 2004; Pesquera et al. 2005; Ertl et al. 2006; Yavuz et al. 2011; Čopjaková et al. 2013), which indicates that the tourmaline structure does not prefer any specific REE. In tourmalines from granitic pegmatites, extensive variations of $\mathrm{La}_{\mathrm{N}} / \mathrm{Yb}_{\mathrm{N}}(0.16-433)$ as well as variable $\mathrm{Eu} / \mathrm{Eu}^{*}$ (0.005-16) were reported (Jolliff et al. 1987; Hellingwerf et al. 1994; Roda et al. 1995; Ertl et al. 2006; Bačík et al. 2012). Nevertheless, the relation of the shape of $\mathrm{Y}+\mathrm{REE}$ patterns in tourmalines to the signature of the host granitic pegmatites (LCT/NYF), degree of fractionation, tourmaline origin (magmatic/hydrothermal) and mineral assemblages is poorly understood.

Tourmalines from the less evolved (b) euxenite-type pegmatites Pozd'átky, Okrašovice and Klučov II show average $\mathrm{Y}+\mathrm{REE}$ contents and their patterns are similar to the host pegmatite unit (compare Fig. $4 \mathrm{a}-\mathrm{c}$ and $4 \mathrm{f}$ ). 
Similarities between the REE contents and patterns in magmatic tourmaline and the whole-rock were documented from granites and orthogneisses worldwide (e.g. Torres-Ruiz et al. 2003; Raith et al. 2004; Pesquera et al. 2005). Based on the experiments, van Hinsberg (2011) determined that the partition coefficients for REE between tourmaline and silicate melt are invariably close to 1 suggesting that tourmaline does not selectively incorporate specific REE into its structure. The contents of $Y+R E E$ and their patterns in the studied tourmalines are consistent with the formation from melt. Calculated partition coefficients based on the average REE ( $\mathrm{La}-\mathrm{Gd})$ contents in tourmalines from the (b) euxenite-type pegmatites (Pozd'átky, Okrašovice, Klučov II) and wholerock analyses are invariably close to unity $(0.42-1.24$; Tab. 5) and roughly agree with the experimental data of van Hinsberg (2011). However, calculated partition

Tab. 5 Mean values of partition coefficients $\left(\mathrm{D}_{\mathrm{T} / \mathrm{WR}}\right)$ for $\mathrm{La}-\mathrm{Gd}$

\begin{tabular}{llllllll}
\hline & $\mathrm{La}$ & $\mathrm{Ce}$ & $\mathrm{Pr}$ & $\mathrm{Nd}$ & $\mathrm{Sm}$ & $\mathrm{Eu}$ & $\mathrm{Gd}$ \\
\hline $\mathrm{D}_{\text {Tu/WR }}$ (this study) & 1.24 & 0.75 & 0.57 & 0.48 & 0.42 & 0.51 & 0.59 \\
$\mathrm{D}_{\text {Tu/melt }}$ (van Hinsberg 2011) & 0.50 & 0.57 & 0.36 & 0.51 & 0.64 & 0.84 & 1.10 \\
\hline calculated using average contents in tourmaline divided by those in the \\
whole-rock analyses. The tourmaline-melt partition coefficients $\mathrm{D}_{\text {Tu/melt }}$ \\
determined by van Hinsberg (2011) are given for comparison.
\end{tabular}

coefficients $\mathrm{D}_{\mathrm{Tu} / \mathrm{WR}}$ from the current study decrease from La to Sm unlike those of van Hinsberg (2011) which rise slightly with increasing atomic number.

The tourmalines that crystallized from late magmatichydrothermal fluids seem to be depleted in REE with higher $\mathrm{La}_{\mathrm{N}} / \mathrm{Yb}_{\mathrm{N}}$ ratios relative to the associated meltderived tourmalines (Jolliff et al. 1987; Pesquera et al. 2005). Later, probably metasomatic fluor-elbaite (d-Tu2) from the Kracovice pegmatite partly replacing early Alrich schorl (d-Tu1) shows significantly lower Y + REE contents; however, chondrite-normalized patterns are flatter. This may be related to elevated contents of $\mathrm{F}$ in late magmatic-hydrothermal fluids manifested by high $\mathrm{F}$ in tourmalines and common F-rich minerals at Kracovice (topaz, Li-micas, F-rich hambergite; Novák et al. 1998b, 1999a, 2012). Hence, strong complexation of HREE by F-rich fluids (Wood 1990) is likely. In contrast, magmatic tourmaline cores (REE 110-220 ppm) from the Forshammar pegmatite are rimmed by REE-rich tourmaline (up 1200 ppm) which Bačík et al. (2012) considered to be due to crystallization at hydrothermal stage.

The contents of Sc in tourmalines from the Třebíc Pluton (up to $765 \mathrm{ppm}$ ) belong to the highest published to date. Even higher Sc contents (up 1290 ppm) described Cempírek et al. (2013) from vanadian oxy-dravite in graphitic quartzites. Lyakhovich and Lyakhovich (1983) reported $222 \mathrm{ppm} \mathrm{Sc}$ in tourmaline from pegmatites, and Ertl et al. (2006) $140 \mathrm{ppm} \mathrm{Sc}$, and equivalent content $\sim 150 \mathrm{ppm}$ of REE, in elbaite from the Anjanabonoina pegmatite, Madagascar. The evolutionary trends of Sc in tourmaline from the examined NYF and mixed (NYF + LCT) pegmatites (b, c, d) mimic those of REE (Fig. 5a), reflecting their similar geochemical behavior. Our results show very high $\mathrm{Sc}$ contents in tourmaline, even compared with $\mathrm{Y}+\mathrm{REE}(\mathrm{Sc} /(\mathrm{Y}+\mathrm{REE}) \sim 2-9)$. However, the extraordinarily high contents of $\mathrm{Sc}$ in tourmalines compared to the whole-rock analyses (less than $1 \mathrm{ppm} \mathrm{Sc}$ ) do not agree with the low distribution coefficients for $\mathrm{Sc}$ $\left(\mathrm{D}_{\text {Tu/melt }} \sim 0.71\right)$ determined experimentally by van Hinsberg (2011). Tourmaline seems to have scavenged effectively Sc from the melt in the studied pegmatites. Moreover, no other Sc-rich minerals have been identified in the studied tourmaline-bearing euxenite-type pegmatites. This seems to be supported by the presence of several Sc-bearing minerals (Sc-enriched beryl, or bazzite, $\mathrm{Be}_{3} \mathrm{Sc}_{2} \mathrm{Si}_{6} \mathrm{O}_{18}$ - Novák and Filip 2010; phase close to $\mathrm{ScNbO}_{4}$ - unpublished data of authors) in the nearby tourmaline-free euxenite-type Kožichovice II pegmatite.

\subsection{Evolutionary trends of trace elements in tourmaline and melt fractionation}

The variations of the major and minor elements in the tourmaline show that the $\mathrm{Mn}$ contents in tourmalines increase with increasing degree of fractionation. Hence, the $\mathrm{Mn}$ concentrations were chosen as an indicator of fractionation and used in the binary plots showing evolutionary trends of relevant trace elements in tourmaline (Fig. 7).

\subsubsection{Europium anomalies}

The Eu anomalies in tourmalines systematically change with the Mn contents (Fig. 7a) from the most primitive (b) euxenite-type Pozd'átky pegmatite (significantly positive $\left.\mathrm{Eu} / \mathrm{Eu}^{*}\right)$, through Okrašovice and Klučov II pegmatites $\left(\mathrm{Eu} / \mathrm{Eu}^{*} \sim 1\right)$ to the most evolved (c) euxenite-type Klučov I pegmatite and mixed (NYF + LCT) Kracovice pegmatite (substantially negative Eu anomalies). It is consistent with increasing degrees of melt fractionation. Moreover, the $\mathrm{Eu}$ anomalies in the tourmalines mimic those of the host pegmatite units in (b) euxenite-type pegmatites (compare Fig. $4 \mathrm{a}-\mathrm{c}$ and $4 \mathrm{f}$ ). Variability in the $\mathrm{Eu}$ anomalies from tourmalines in the Okrašovice pegmatite is related to their paragenetic position: (i) the positive ones in tourmaline grains from quartz-rich domain, and (ii) weak negative Eu anomalies in tourmaline from K-feldspar-rich domain. It may rather reflect local depletion of $\mathrm{Eu}^{2+}$ in the melt due to its consumption during growth of $\mathrm{K}$-feldspar, an important carrier of $\mathrm{Eu}^{2+}$ in magmatic rocks (e.g., Bea 1996). Nevertheless, no 


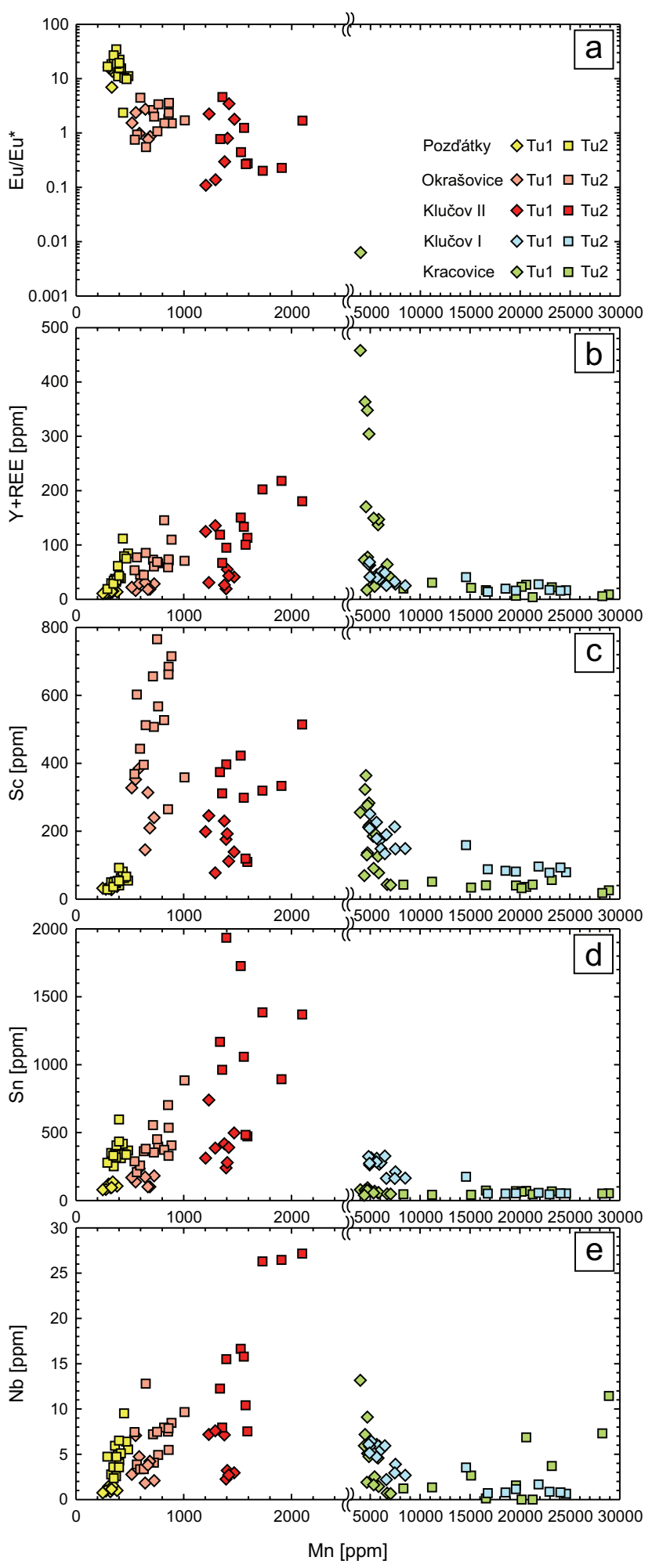

Fig. 7 Evolution of the trace elements (LA-ICP-MS data) during the tourmaline growth demonstrated on binary plots: $\mathrm{Eu} / \mathrm{Eu}^{*}$ vs. $\mathrm{Mn}(\mathbf{a})$; $\mathrm{Y}+\mathrm{REE}$ vs. Mn (b); Sc vs. Mn (c); Nb vs. Mn (d); Sn vs. Mn (e). Note the break on the horizontal $\mathrm{x}$-axis. The symbols are the same as in Fig. 3. relations between Eu anomaly in tourmaline and its textural position to K-feldspars were observed at the other localities. In Pozd'átky, the tourmaline is enclosed solely by K-feldspar while in Klučov II, the small K-feldspar grains are randomly distributed around the tourmaline crystals in quartz matrix.

\subsubsection{Trace-element contents in tourmalines from the (b) euxenite-type pegmatites}

There is an apparent coherent rise in the $\mathrm{Y}+\mathrm{REE}, \mathrm{Sc}$, $\mathrm{Nb}$ and $\mathrm{Sn}$ contents with $\mathrm{Mn}$ during the tourmaline evolution from dravite (b-Tu1) to Ca-rich dravite (b-Tu2). Moreover, similar increase was observed in the sequence Pozd'átky $\rightarrow$ Okrašovice $\rightarrow$ Klučov II (Fig. 7), and for $\mathrm{Y}+\mathrm{REE}$ and $\mathrm{Nb}$ it corresponds with the whole-rock concentrations (Pozd'átky $\rightarrow$ Okrašovice $\rightarrow$ Klučov II; Tab. 4). The observed trends indicate a general increase in $\mathrm{Y}+\mathrm{REE}, \mathrm{Sc}, \mathrm{Nb}, \mathrm{Sn}$ in the melt with its progressive fractionation. This is enhanced by the very low wholerock content of $\mathrm{P}_{2} \mathrm{O}_{5}$ (less than 0.02 wt. \%), which probably prevented precipitation of $\mathrm{Y}+$ REE phosphates at the early stages of pegmatite crystallization, and enabled incorporation of these elements into tourmalines. Similarly, low contents of $\mathrm{Ca}$ in the melt $(0.1-0.8 \mathrm{wt} . \% \mathrm{CaO}$ in the whole-rock analyses of relevant tourmaline-bearing pegmatite units; Tab. 4) prevented precipitation of allanite (Cuney and Friedrich 1987; Casillas et al. 1995) in the tourmaline-bearing pegmatite units. However, rare allanite crystallized earlier in tourmaline-free outer granitic unit; hence, part of the LREE could have been exhausted earlier on.

The crystallization of quartz and feldspars caused the rising $\mathrm{Y}+\mathrm{REE}, \mathrm{Sc}, \mathrm{Nb}$ and $\mathrm{Sn}$ in the melt, recorded in the tourmaline trace-element geochemistry. Such a geochemical evolution is in accord with textural observations. The $\mathrm{Y}+\mathrm{REE}$-bearing minerals (aeschynite- and euxenite-group minerals) seem to be later than tourmaline in the (b) euxenite type pegmatites.

\subsubsection{Trace-element contents in tourmalines from more evolved (c) Klučov I and (d) Kracovice pegmatites}

The contents of $\mathrm{Y}+\mathrm{REE}, \mathrm{Sc}$, and $\mathrm{Nb}$ in tourmalines from the more evolved Klučov I and Kracovice pegmatites systematically decreased during crystallization of schorl (c-Tu1) and Al-rich schorl (d-Tu1) with increasing Mn content and melt evolution (Fig. 7b-d). The later tourmaline generation, Al-rich schorl (c-Tu2) and fluor-elbaite (d-Tu2) show significantly lower REE and Sc than the early generation (c-Tu1) and (d-Tu1), moreover, the Y + REE patterns become flatter. In contrast, fluor-elbaite 
(d-Tu2) shows weak $\mathrm{Nb}$ enrichment along with rising $\mathrm{Mn}$ (Fig. 7d). The coherent steeply decreasing trend of $Y+$ $\mathrm{REE}, \mathrm{Sc}$ and $\mathrm{Nb}$ with increasing $\mathrm{Mn}$, observed during crystallization of the first tourmaline generation in the Klučov I and Kracovice pegmatites, was likely caused by coeval crystallization of $\mathrm{Y}+\mathrm{REE}$ - and Nb-bearing minerals (columbite- and aeschynite-group minerals, monazite-(Ce) in the Klučov I pegmatite; samarskite- and columbite-group minerals, monazite-(Ce), xenotime-(Y) and $\mathrm{Y}+\mathrm{Sc}$-rich spessartine in the Kracovice pegmatite, respectively). Their precipitation effectively removed these elements from the melt. The decreasing REE in tourmaline from the wall zone toward the pegmatite core probably reflect progressive crystallization of the pegmatite, as was described by Jolliff et al. (1987) from a large zoned lepidolite-subtype LCT pegmatite Bob Ingersoll, S. Dakota (USA).

The crystallization of cassiterite, before and during the growth of the first tourmaline generation (c-Tu1) in the Klučov I pegmatite, explains the drop in Sn with increasing Mn (Fig. 7e). Systematically low Sn contents in the second tourmaline generation (c-Tu2) in the Klučov I pegmatite as well as in the both tourmaline generations in the Kracovice pegmatite (d-Tu1) and (d-Tu2) suggest their crystallization from the Sn-depleted melt.

\subsubsection{Effect of zircon crystallization on $Y+R E E$ patterns in tourmaline}

Zircon commonly contains elevated concentrations of $\mathrm{Y}+$ REE (Hoskin and Schaltegger 2003; Förster 2006; Breiter et al. 2006, 2009). Very low $\mathrm{Zr}$ in tourmaline (avg. 1.7 ppm) compared with whole-rock content (24-60 ppm), together with the presence of zircon inclusions in tourmaline, confirm early crystallization of this mineral from the melt. Thus, its crystallization could have affected the melt composition before the tourmaline crystallization and presumably had negligible effect on evolution of $\mathrm{Y}$ + REE patterns during the tourmaline growth.

\subsection{Implications of the study}

The contents of REE in tourmalines were commonly analyzed from bulk samples (dissolved tourmaline separates) using ICP-MS or RNAA (Jolliff et al. 1987; King et al. 1988; Hellingwerf et al. 1994; Roda et al. 1995; TorresRuiz et al. 2003; Raith et al. 2004; Pesquera et al. 2005; Ertl et al. 2006; Garda et al. 2010; Yavuz et al. 2011). Consequently, they may be affected by the presence of accessory minerals inclusions (Pesquera et al. 2005). Moreover, due to large volume of analyzed material, the information concerning REE evolution during tourmaline growth is lost. For these reasons, LA-ICP-MS with its relatively high spatial resolution and low detection lim- its is an ideal analytical method to study trace-element distributions in tourmaline (Novák et al. 2011; Bačík et al. 2012; this work).

Compositional zoning in $\mathrm{Y}$ and $\mathrm{REE}$ has been recently discussed e.g. in garnet, where Y + REE represent a sensitive indicator of garnet growth and crystallization history in metamorphic rocks (e.g., Lanzirotti 1995; Spear and Kohn 1996; Pyle and Spear 1999; Otamendi et al. 2002; Røhr et al. 2007), and also in magmatic rocks (Wang et al. 2003; Müller et al. 2012). It may be also a very useful for provenance studies in sedimentary rocks (Čopjaková et al. 2005). Sensitivity of tourmaline trace-element chemistry (including Y + REE) to the composition of its highly variable host rocks (e.g., Torres-Ruiz et al. 2003; Raith et al. 2004; Pesquera et al. 2005; van Hinsberg 2011; this work), makes it a useful tool for interpretation of the growth environment as well as for provenance studies of sedimentary assemblages. However, a combination with the nature, chemistry and crystallization sequence of associated accessory minerals is required to reveal behavior of $Y+R E E$ and further trace elements during the tourmaline growth.

Acknowledgements. The authors are very grateful to the reviewers Darrell Henry and Peter Bačík for constructive criticism that improved the manuscript. The authors thank Pavel Uher and Vojtěch Janoušek for editorial handling. This paper was supported by the research project GAČR P210/10/0743 to RČ, RS and MN. MVG acknowledges the European Regional Development Fund project "CEITEC" (CZ.1.05/1.1.00/02.0068).

\section{References}

Bačík P, Uher P, Ertl A, Jonsson E, Nysten P, Kanický V, VACULOVIČ T (2012) Zoned REE-enriched dravite from a granitic pegmatite in Forshammar, Bergslagen Province, Sweden: an EMPA, XRD and LA-ICP-MS study. Canad Mineral 50: 825-841

BaČík P, Cempírek J, Uher P, NovÁk M, Ozdín D, Filip J, ŠKoda R, Breiter K, Klementová M, Ďuña R (2013) Oxy-schorl, $\mathrm{Na}\left(\mathrm{Fe}^{2+}{ }_{2} \mathrm{Al}\right) \mathrm{Al}_{6} \mathrm{Si}_{6} \mathrm{O}_{18}\left(\mathrm{BO}_{3}\right)_{3}(\mathrm{OH})_{3} \mathrm{O}$, a new mineral from Zlatá Idka, Slovak Republic and Přibyslavice, Czech Republic. Amer Miner 98: 485-492

BEA F (1996) Residence of REE, Y, Th and $U$ in granites and crustal protoliths; implications for the chemistry of crustal melts. J Petrol 37: 521-552

Breiter K, Förster, H-J, ŠKodA, R (2006) Extreme P-, Bi-, $\mathrm{Nb}-, \mathrm{Sc}-, \mathrm{U}-$ and F-rich zircon from fractionated perphosphorous granites: the peraluminous Podlesí granite system, Czech Republic. Lithos 88: 15-34

Breiter K, Čopjaková R, ŠKoda R (2009) The involvement of $\mathrm{F}, \mathrm{CO}_{2}$, and As in the alteration of $\mathrm{Zr}$-Th-REEbearing accessory minerals in the Hora Svaté Kateřiny 
A-type granite, Czech Republic. Canad Mineral 47: 1375-1398

BuriáneK D, NovÁK M (2007) Compositional evolution and substitutions in disseminated and nodular tourmaline from leucocratic granites: examples from the Bohemian Massif, Czech Republic. Lithos 95: 148-164

Casillas R, Nagy G, Pantó G, Brandle J, Fórizs I (1995) Occurrence of Th, U, Y, Zr and REE-bearing accessory minerals in late-Variscan granitic rocks from the Sierra Guadarrama (Spain). Eur J Mineral 7: 989-1006

Cempírek J, Houzar S, Novák M, Groat LA, Selway JB, Śrein V (2013) Crystal structure and compositional evolution of vanadium-rich oxy dravite from graphite quartzite at Bítovánky, Czech Republic. J Geosci 58: 149-162

Cuney M, Friedrich M (1987) Physicochemical and crystalchemical controls on accessory mineral paragenesis in granitoids: implications for uranium metallogenesis. Bull Minerál 110: 235-247

ČERNÝ P, ERCIT TS (2005) Classification of granitic pegmatites. Canad Mineral 43: 2005-2026

Černý P, London D, NovÁK M (2012) Granitic pegmatites as reflections of their sources. Elements 8: 289-294

Čopjaková R, Sulovský P, Paterson BA (2005) Major and trace elements in pyrope-almandine garnets as sediment provenance indicators of the Lower Carboniferous Culm sediments, Drahany Uplands, Bohemian Massif. Lithos 82: 51-70

Čopjaková R, Š́Koda R, Novák M, Vašinová Galiová $M$ (in print) Geochemistry of $\mathrm{Y}+\mathrm{REE}$ in stratiform tourmalinites and their tourmalines: implications for their genesis. Abstract book, $12^{\text {th }}$ SGA Biennial Meeting (Uppsala, Sweden)

Dutrow BL, Henry DJ (2000) Complexly zoned fibrous tourmaline, Cruzeiro Mine, Minas Gerais, Brazil: a record of evolving magmatic and hydrothermal fluids. Canad Mineral 38: 131-143

Dutrow BL, Henry DJ (2011) Tourmaline: a geologic DVD. Elements 7: 301-306

Ercit TS, Groat LA, Gault RA (2003) Granitic pegmatites of the O'Grady Batholith, N.W.T., Canada: a case study of the evolution of the elbaite subtype of rare-element granitic pegmatites. Canad Mineral 41: 117-137

Ertl A, Hughes JM, Prowatke S, Ludwig T, Prasad PSR, Brandstätter F, Körner W, Schuster R, Pertlik F, MARSCHALl H (2006) Tetrahedrally coordinated boron in tourmalines from the liddicoatite-elbaite series from Madagascar: structure, chemistry, and infrared spectroscopic studies. Amer Miner 91: 1847-1856

Federico M, Andreozzi GB, Lucchesi S, Graziani G, CésarMendes J (1998) Compositional variation of tourmaline in the granitic pegmatite dykes of the Cruzeiro Mine, Minas Gerais, Brazil. Canad Mineral 36: 415-431

FÖRSTER H-J (2006) Composition and origin of intermediate solid solutions in the system thorite-xenotime-zirconcoffinite. Lithos 88: 35-55

Garda GM, Beljavskis P, D’Agostino LZ, Wiedenbeck M (2010) Tourmaline and rutile as indicators of a magmatichydrothermal origin for tourmalinite layers in the São José do Barreiro Area, NE Ribeira Belt, southern Brazil. Geol USP Sér cient São Paulo 10: 97-117

Hawthorne FC, Henry DJ (1999) Classification of the minerals of the tourmaline group. Eur J Mineral 11: 201-215

Hellingwerf RH, Gatedal K, Gallagher V, Baker JH (1994) Tourmaline in the central Swedish ore district. Miner Depos 29: 189-205

Henry DJ, Dutrow BL (1996) Metamorphic tourmaline and its petrologic applications. In: Grew ES, ANOvitz LM (eds) Boron: Mineralogy, Petrology and Geochemistry. Mineralogical Society of America Reviews on Mineralogy 33: 503-557

Henry DJ, Novák M, Hawthorne FC, Ertl A, Dutrow BL, Uher P, Pezzotta F (2011) Nomenclature of the tourmaline-group minerals. Amer Miner 96: 895-913

Holub FV (1997) Ultrapotassic plutonic rocks of the durbachite series in the Bohemian Massif: petrology, geochemistry and petrogenetic interpretation. Sbor geol Věd, ložisk Geol Mineral 31: 5-26

Holub FV, Cocherie A, Rossi P (1997) Radiometric dating of granitic rocks from the Central Bohemian Plutonic Complex (Czech Republic): constraints on the chronology of thermal and tectonic events along the Moldanubian-Barrandian boundary. CR Acad Sci Paris Earth Planet Sci 325: 19-26

Hoskin PWO, Schaltegger U (2003) The composition of zircon and igneous and metamorphic petrogenesis. In: Hanchar JM, Hoskin PWO (eds) Zircon. Mineralogical Society of America and Geochemical Society Reviews in Mineralogy and Geochemistry 53: 27-62

JANOUŠEK V, HoLuB FV (2007) The causal link between HPHT metamorphism and ultrapotassic magmatism in collisional orogens: case study from the Moldanubian Zone of the Bohemian Massif. Proc Geol Assoc 118: 75-86

Janoušek V, Bowes DR, Rogers G, Farrow CM, Jelínek E (2000) Modelling diverse processes in the petrogenesis of a composite batholith: the Central Bohemian Pluton, Central European Hercynides. J Petrol 41: 511-543

JANOUŠEK V, Holub FV, Gerdes A (2003) K-rich magmatism in the Moldanubian Unit, Bohemian Massif - a complex story featuring variably enriched lithospheric mantle melts and their interaction with the crust. Geolines 16: 48-49

JiANG S-Y, Yu J-Mm Lu J-J (2004) Trace and rare-earth element geochemistry in tourmaline and cassiterite from the Yunlong tin deposit, Yunnan, China: implication for migmatitic-hydrothermal fluid evolution and ore genesis. Chem Geol 209: 193-213

Jiang S-Y, Radvanec M, Nakamura E, Palmer M, Ko- 
BAyashi K, Zhao HX, Zhao KD (2008) Chemical and boron isotopic variations of tourmaline in the Hnilec granite-related hydrothermal system, Slovakia: constraints on magmatic and metamorphic fluid evolution. Lithos 106: 1-11

Jolliff BL, Papike JJ. Shearer CK (1986) Tourmaline as a recorder of pegmatite evolution: Bob Ingersol pegmatite, Black Hills, South Dakota. Amer Miner 71: 472-500

Jolliff BL, Papike JJ, Laul JC (1987) Mineral recorders of pegmatite internal evolution: REE contents of tourmaline from the Bob Ingersoll pegmatite, South Dakota. Geochim Cosmochim Acta 51: 2225-2232

KING RW, KERRICH RW, DADDAR R (1988) REE distributions in tourmaline: an INAA technique involving pretreatment by B volatilization. Amer Miner 73: 424-431

Kontak DJ, Dostal J, Kyser K, Archibald DA (2002) A petrological, geochemical, isotopic and fluid inclusion study of 370 Ma pegmatite-aplite sheets, Peggys Cove, Nova Scotia, Canada. Canad Mineral 40: 1249-1286

Kotková J, Schaltegger U, Leichmann J (2010) Two types of ultrapotassic plutonic rocks in the Bohemian Massif - coeval intrusions at different crustal levels. Lithos 115: $163-176$

Kusiak MA, Dunkley DJ, Suzuki K, Kachlík V, KęDzior A, LekKi J, Opluštil S (2010) Chemical (non-isotopic) and isotopic dating of Phanerozoic zircon - a case study of durbachite from the Třebíč Pluton, Bohemian Massif. Gondwana Res 17: 153-161

LANZIROTTI A (1995) Yttrium zoning in metamorphic garnets. Geochim Cosmochim Acta 59: 4105-4110

London D, Manning DA (1995) Chemical variation and significance of tourmaline from southwest England. Econ Geol 90: 495-519

London D, Morgan GBVI, Wolf MB (1996) Boron in granitic rocks and their contact aureoles. In: GREw ES, Anovitz LM (eds) Boron: Mineralogy, Petrology and Geochemistry. Mineralogical Society of America Reviews on Mineralogy 33: 299-330

LYAKHOVICH TT, LYAKHOVICH VV (1983) New data on accessory-mineral compositions. Geochem Inter 20: 91-108

McDonough WF, Sun SS (1995) Composition of the Earth. Chem Geol 120: 223-253

Melleton J, Gloaguen E, Frei D, Novák M, Breiter $\mathrm{K}$ (2012) How are the emplacement of rare-element pegmatites, regional metamorphism and magmatism interrelated in the Moldanubian domain of the Variscan Bohemian Massif, Czech Republic? Canad Mineral 50: 1751-1773

MeRLET C (1994) An accurate computer correction program for quantitative electron probe microanalysis. Microchim Acta 114/115: 363-376

Morgan GBVI, London D (1999) Crystallization of the Little Three layered pegmatite-aplite dike, Ramona District, California. Contrib Mineral Petrol
136: $310-330$

Müller A, Kaersley A, Spratt J, Seltmann R (2012) Petrogenetic implications of magmatic garnet in granitic pegmatites from southern Norway. Canad Mineral 50: 1095-1115

NĚMEC D (1990) Neues zur Mineralogie eines Hambergitführenden Pegmatitigangs von Kracovice (bei Třebíć, Westmorava, ČSFR). Z geol Wiss 18: 1105-1115

NovÁ́ M (2000) Compositional pathways of tourmaline evolution during primary (magmatic) crystallization in complex (Li) pegmatites of the Moldanubicum, Czech Republic. Mem Soc Italiana Scienze Nat Mus Civ Storia Nat, Milano 30: 45-56

NovÁK M, FiLIP J (2010) Unusual (Na,Mg)-enriched beryl and its breakdown products (beryl II, bazzite, bavenite) from euxenite-type NYF pegmatite related to the orogenic ultrapotassic Třebíč Pluton, Czech Republic. Canad Mineral 48: 615-628

NovÁK M, PovondRa P (1995) Elbaite pegmatites in the Moldanubicum: a new subtype of the rare-element class. Mineral Petrol 55: 159-176

Novák M, Černý P, Kimbrough DL, Taylor MC, Ercit TS (1998a) U-Pb ages of monazite from granitic pegmatites in the Moldanubian Zone and their geological implications. Acta Univ Carol, Geol 42: 309-310

Novák M, Burns PC, Morgan VI GB (1998b) Fluorine variation in hambergite from granitic pegmatites. Canad Miner 36: 441-446

Novák M, Selway JB, Černý P, Hawthorne FC (1999a) Tourmaline of the elbaite-dravite series from an elbaitesubtype pegmatite at Bližná, southern Bohemia, Czech Republic. Eur J Mineral 11: 557-568

Novák M, ČERnÝ P, Selway JB (1999b) The zinnwalditemasutomilite-elbaite pegmatite at Kracovice from the Třebíč durbachite massif - a complex pegmatite related to the NYF family. In: MarTin RF (ed) The Eugene E. Foord Memorial Symposium on NYF-type Pegmatites, Denver, Colorado. Canad Mineral 37: 815-816

Novák M, Povondra P, Selway JB (2004) Schorl-oxyschorl to dravite-oxy-dravite tourmaline from granitic pegmatites; examples from the Moldanubicum, Czech Republic. Eur J Mineral 16: 323-333

Novák M, Š́oda R, Filip J, Macek I, Vaculovič T (2011) Compositional trends in tourmaline from intragranitic NYF pegmatites of the Třebíč Pluton, Czech Republic: an electron microprobe, Mössbauer and LA-ICP-MS study. Canad Mineral 49: 359-380

Novák M, Š́oda R, Gadas P, Krmíček L, Černý P (2012) Contrasting origins of the mixed (NYF + LCT) signature in granitic pegmatites, with examples from the Moldanubian Zone, Czech Republic. Canad Mineral 50: 1077-1094

Novák M, Ertl A, Povondra P, Vašinová Galiová M, Rossman GR, Pristacz H, Prem M, Giester G, GaDAS P, ŠKoDA R (in print) Darrellhenryite, $\mathrm{Na}\left(\mathrm{LiAl}_{2}\right)$ 
$\mathrm{Al}_{6}\left(\mathrm{BO}_{3}\right)_{3} \mathrm{Si}_{6} \mathrm{O}_{18}(\mathrm{OH})_{3} \mathrm{O}$, a new mineral from the tourmaline supergroup. Amer Miner 98

Otamendi JE, de la Rosa JD, Patino Douce AE, Castro A (2002) Rayleigh fractionation of heavy rare earths and yttrium during metamorphic garnet growth. Geology 30: $159-162$

Pesquera A, Torres-Ruiz J, Gil-Crespo PP, Jiang S-Y (2005) Petrographic, chemical and B-isotopic insights into the origin of tourmaline-rich rocks and boron recycling in the Martinamor Antiform (Central Iberian Zone, Salamanca, Spain). J Petrol 46: 1013-1044

PovondRa P (1981) The crystal chemistry of tourmalines of the schorl-dravite series. Acta Univ Carol, Geol 3: 223-264

Povondra P, Čéh F, StaněK J (1985) Crystal chemistry of elbaites from some lithium pegmatites of the Czech Massif. Acta Univ Carol, Geol 1: 1-24

Pyle JM, Spear FS (1999) Yttrium zoning in garnet: coupling of major and accessory phases during metamorphic reactions. Geol Mat Res 1: 1-49

Raith JG, Riemer N, Schöner N, Meisel T (2004) Boron metasomatism and behavior of rare earth elements during formation of tourmaline rocks in the eastern Arunta Inlier, central Australia. Contrib Mineral Petrol 147: 91-109

Roda E, Pesquera A, Velasco F (1995) Tourmaline in granitic pegmatites and their country rocks, Fregeneda area, Salamanca, Spain. Canad Mineral 33: 835-848

RøHr TS, Austrheim H, ERAMBerT M (2007) Stress-induced redistribution of yttrium and heavy rare-earth elements (HREE) in garnet during high-grade polymetamorphism. Amer Miner 92: 1276-1287

Selway JB, Novák M, Hawthorne FC, Černý P, Ottolini L, KYSER TK (1998) Rossmanite, $\square\left(\mathrm{LiAl}_{2}\right) \mathrm{Al}_{6}\left(\mathrm{Si}_{6} \mathrm{O}_{18}\right)$ $\left(\mathrm{BO}_{3}\right)_{3}(\mathrm{OH})_{4}$, a new alkali-deficient tourmaline; description and crystal structure. Amer Miner 83: 896-900

Selway JB, Novák M, Černý P, Hawthorne FC (1999) Compositional evolution of tourmaline in lepidolite-subtype pegmatites. Eur J Mineral 11: 569-584

Selway JB, Černý P, Hawthorne FC, Novák M (2000) The Tanco pegmatite at Bernic Lake, Manitoba. Canad Mineral 38: 1103-1117

Spear FS, KoHn MJ (1996) Trace element zoning in garnet as a monitor of crustal melting. Geology 24: 1099-1102

ŠKODA R, ČOPJAKOVÁ R (2005) Unusual Sn mineralization from the NYF pegmatite near Klučov, Třebíč Pluton, Moldanubicum. Geol Výzk Mor Slez v r. 2004: 93-97 (in Czech with English summary)

ŠKoda R, NovÁK M (2007) Y,REE,Nb,Ta,Ti-oxide $\left(\mathrm{AB}_{2} \mathrm{O}_{6}\right)$ minerals from REL-REE euxenite-subtype pegmatites of the Třebíč Pluton, Czech Republic; substitutions and fractionation trends. Lithos 95: 43-57

ŠKoda R, NovÁk M, HouZar S (2006) Granitic NYF pegma- tites of the Třebíč Pluton. Acta Mus Moraviae, Sci geol 91: 129-176 (in Czech with English summary).

Tindle AG, Breaks FW, Selway JB (2002) Tourmaline in petalite subtype granitic pegmatites: evidence of fractionation and contamination from the Pakeagama Lake and Separation Lake areas of northwestern Ontario, Canada. Canad Mineral 40: 753-788

Torres-Ruiz J, Pesquera A, Gil-Crespo PP, Velilla N (2003) Origin and petrogenetic implications of tourmaline-rich rocks in the Sierra Nevada (Betic Cordillera, southeastern Spain). Chem Geol 197: 55-86

van Hinsberg VJ (2011) Preliminary experimental data on trace-element partitioning between tourmaline and silicate melt. Canad Mineral 49: 153-163

van Hinsberg VJ, Henry DJ, Dutrow BL (2011a) Tourmaline as a petrologic forensic mineral: a unique recorder of its geologic past. Elements 7: 327-332

van Hinsberg VJ, Henry DJ, Marschall HR (2011b) Tourmaline: an ideal indicator of its host environment. Canad Mineral 49: 1-16

Wang RC, Hu H, Zhang A, Xu S, Wang D (2003) Yttrium zoning in garnet from the Xihuashan granitic complex and its petrologic implications. Chin Sci Bull 48: $1611-1615$

WhitNEy DL, EvANs BW (2010) Abbreviations for names of rock-forming minerals. Amer Miner 95: 185-187

Wood SA (1990) The aqueous geochemistry of the rare-earth elements and yttrium. 1. Review of available low-temperature data for inorganic complexes and the inorganic REE speciation of natural waters. Chem Geol 82: $159-186$

YAVUZ F, IsKenderoĞLu A, JiANG S-Y (1999) Tourmaline compositions from the Salikvan porphyry $\mathrm{Cu}-\mathrm{Mo}$ deposit and vicinity, northeastern Turkey. Canad Mineral 37: 1007-1023

Yavuz F, Jiang S-Y, Karakaya N, Karakaya MC, Yavuz R (2011) Trace-elements, rare-earth element and boron isotopic compositions of tourmaline from a vein-type $\mathrm{Pb}-\mathrm{Zn}-\mathrm{Cu} \pm \mathrm{U}$ deposit, NE Turkey. Int Geol Rev 53: $1-24$

Zhang IC, Wang RC, Juany SY, Hu H, Zhang H (2008) Chemical and textural features of tourmaline from the spodumene-subtype Koktokay No. 3 pegmatite, Altai, northwestern China: a record of magmatic to hydrothermal evolution. Canad Mineral 46: 41-58

ŽÁx J, Holub FV, Verner K (2005) Tectonic evolution of a continental magmatic arc from transpression in the upper crust to exhumation of mid-crustal orogenic root recorded by episodically emplaced plutons: the Central Bohemian Plutonic Complex (Bohemian Massif). Int J Earth Sci (Geol Rundsch) 94: 385-400 